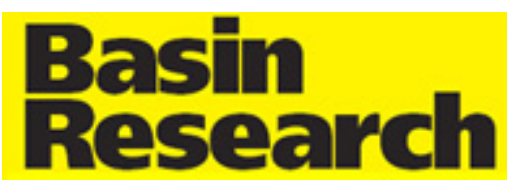

IAS EAGE

\title{
TECTONO-SEDIMENTARY EVOLUTION OF TRANSVERSE EXTENSIONAL FAULTS IN A FORELAND BASIN: RESPONSE TO CHANGES OF TECTONIC PLATE PROCESSES
}

\begin{tabular}{|r|l|}
\hline Journal: & Basin Research \\
\hline Manuscript ID & BRE-127-2019.R2 \\
\hline Manuscript Type: & Original Article \\
\hline Complete List of Authors: & $\begin{array}{l}\text { Carrillo, Emilio; University Yachay Tech; Universitat de Barcelona } \\
\text { Guinea, Ander; Federation University Australia, School of Science, } \\
\text { Engineering and Information Technology } \\
\text { Casas, Albert; Universitat de Barcelona } \\
\text { Rivero, Lluis; University of Barcelona } \\
\text { Cox, Nicole; Federation University Australia } \\
\text { Vázquez, Yaniel; University Yachay Tech; Universitat de Barcelona }\end{array}$ \\
\hline Keywords: & $\begin{array}{l}\text { foreland basins, geodynamics, modelling, sequence stratigraphy, } \\
\text { structure, tectonics and sedimentation, strike-slip basins }\end{array}$ \\
\hline & \\
\hline
\end{tabular}

\section{SCHOLARONE \\ Manuscripts}


TECTONO-SEDIMENTARY EVOLUTION OF TRANSVERSE EXTENSIONAL FAULTS IN A FORELAND BASIN: RESPONSE TO CHANGES OF TECTONIC PLATE PROCESSES

Emilio Carrillo ${ }^{\left(a, b,{ }^{*}\right)}$, Ander Guinea ${ }^{(c)}$, Albert Casas ${ }^{(a)}$, Lluis Rivero ${ }^{(a)}$, Nicole Cox ${ }^{(c)}$ and Yaniel Misael Vázquez-Taset ${ }^{(b, d)}$

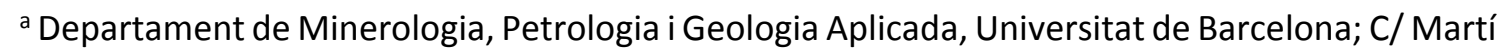

i Franqués, s/n; 08028 Barcelona, Spain

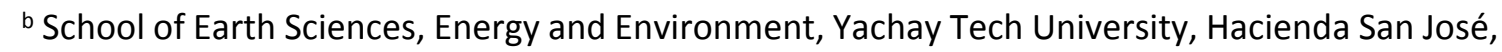
s/n, San Miguel de Urcuquí, Ecuador

c Federation University Australia; School of Science, Engineering and Information Technology;

Ballarat, Australia

d Geomodels Research Institute. Departament de Geodinàmica de la Terra i de I'Oceà, Universitat de Barcelona; C/ Martí i Franqués, s/n; 08028 Barcelona, Spain

${ }^{*}$ Corresponding author

\section{ACKNOWLEDGEMENTS}

This study was supported by projects CGL2005-05337 and CGL2009-11096 of the Spanish Government (Ministerio de Educación y Ciencia and Ministerio de Ciencia e Innovación, respectively), project 303754 (CEPSA-Universitat de Barcelona) and project 2009SGR1451 of the Catalan Government (Departament d'Innovació, Universitats i Empresa). Emilio Carrillo benefited from a grant (BES-2006-12381) of the Spanish Government (Ministerio de Educación y Ciencia). Some methods were developed using an academic license of the software Move, by Midland Valley Exploration Limited. Thanks are due to Schlumberger for a donation of Petrel Exploration and Production licenses as well as technical support to use the software. The authors are indebted to the following institutions and people for facilitating the study of subsurface data and sampling cores: Agència Catalana de l'Aigua, Institut Geològic de Catalunya, Litoteca de Sondeos (IGME), Jorge Navarro and Jesús Malagón (CEPSA), Dr. María José Jurado (ICTJA-CSIC) and Enric Vinyals. The authors are also indebted to Dr. Laura Rosell and Dr. Federico Ortí (University of Barcelona), and Dr. Jaume Vergés (ICTJA-CSIC) for helpful comments that 
improved the manuscript. Details and useful comments by Christopher Morley, Alex Whittaker, anonymous reviewer, and the Associate Editor Craig Magee improved the manuscript.

\section{Abstract}

Late Paleocene to Middle Eocene strata in the easternmost part of the Southern Pyrenees, up to $4 \mathrm{~km}$ thick, provide information on tectono-sedimentary evolution of faults transversal to the Pyrenean chain. In order to know how changes of tectonic plate processes control the structural evolution of transverse faults and the synchronous thickness and lithological distribution of sedimentary strata in a foreland basin, field observations, interpretation of 2D seismic lines tied to lithostratigraphic data of exploration wells and gravity modelling constrains were carried out. This resulted in the following two tectono-sedimentary phases in a foreland basin: first phase, dominated by transverse extensional faulting, synchronous with deposition of marine carbonates (ca. 57 to $51 \mathrm{Ma}$ ); and second phase, characterized by transverse contractional faulting, coeval to accumulation of marine evaporites and siliciclastics (51 to $44 \mathrm{Ma}$ ). During the first phase, Iberia and Adria were moving to the east and west, respectively. Therefore, lithospheric flexure in the easternmost part of the Iberian plate was developed due to that Sardinia was overthrusting Iberia. Consequently, activation of E-dipping normal faults were generated giving rise to thick-deep and thin-shallow carbonate platform deposits across the hanging walls and footwalls of the transverse structures. During the second phase, a shearing interaction between Iberia and Sardinia prevailed re-activating the transverse faults as contractional structures generating thin-shelf and thick-submarine fan deposits across the hanging walls and footwalls of the transverse structures. In the transition between the first and second phases, evaporitic conditions dominated in the basin suggesting a tectonic control on basin marine restriction. The results of our study demonstrate how thickness and lithology distribution, controlled by transverse faulting in a compressional regimen, are influenced by phases related to processes affecting motions and interactions between tectonic plates and continental blocks.

Keywords: transverse faults; foreland basins; evaporites; Pyrenees; Iberia; Sardinia

\section{INTRODUCTION}

The activation of structures perpendicular (transverse) to the trend of foredeep-bulges in foreland basins has been widely documented. The most common are strike-slip faults whose 
62

generation has been attributed to lateral ramps of thrust sheets and tear displacements from both pre- and early- orogenic structures (e.g., Sylvester, 1988; McDougall and Khan, 1990; Şengör, 1990; Hubbard, 1999; Khun, 2002; Bahroudi and Koyi, 2004; Morley et al., 2009; Turner et al., 2010; Muñoz et al., 2013). By contrast, relatively few studies have documented the development and evolution of transverse extensional faults (Doglioni, 1995; Torelli et al., 1998; Bianca et al., 1999; Tărăpoancă et al., 2003; Billi et al., 2006; Gutscher et al., 2015; Tavani et al., 2015). The generation of transverse extensional faults in a foredeep-bulge can be explained by two mechanisms: (1) along strike stretching (Doglioni, 1995; Zhao and Jacobi, 1997); and (2) noncylindrical forebulges (Billi et al., 2006). In the second mechanism, bending foreland lithosphere is partly surrounded by two orogenic salients. By contrast, the first mechanism has been described using only one orogenic salient.

Several of the previous studies on transverse extensional faults discuss the change of stress directions during a single compressional event (periods of less than $20 \mathrm{Ma}$ ). However, the way in which changes of tectonic plate processes control the structural evolution of transverse faults and the synchronous thickness and lithological distribution of sedimentary strata in a foreland basin has yet to be considered. Addressing this issue should be relevant to consider the tectonosedimentary evolution of transverse faults as key to establish kinematic histories of complex compressional zones. These histories are useful to better explain the present-day activity of seismic and volcanic regions with more than one orogenic salient; such as the Mediterranean region. The tectono-sedimentary evolution of transverse faults can also be used for understanding hydrocarbon and geothermal systems, since it can influence the distribution of thickness of source rocks by the generation of transverse depozones; as well as the quality of reservoirs and fluid migration by the formation of fractures and favoring pathways through these faults.

The Paleocene to Eocene succession of the easternmost part of the southern Pyrenees (Fig. 1A) provides an opportunity to investigate how multiphase transverse faulting in a foreland basin controls thickness and lithology distribution during tectonic plate processes. This area was located along the northeastern margin of the Iberian Plate, which experienced continental collision with Eurasia, Corsica and Sardinia during the Eocene (Fig. 1B) (Lacombe and Jolivet, 2005; Andreani et al., 2010; Advokaat et al., 2014; Bestani et al., 2016). In the Southeastern Pyrenees, NNW-SSE striking faults are present (Fig. 2A), transverse to the main W-E trend of the Pyrenean. These faults were active during the Early Eocene; interpreted as normal faulting, coeval to the Pyrenean compression (Estévez, 1970; Santisteban and Taberner, 1979; Martínez 
et al., 1994). However, there is still considerable uncertainty about the structural evolution, role on the stratigraphy, and regional importance of these transverse faults.

In the present study, we use a robust unpublished seismic reflection and well data set for the Southeastern Pyrenees in conjunction with field observations to: (i) characterize a foreland basin structure; (ii) establish relations between transverse faults and thickness and lithology distributions through time; and (iii) record tectonic events. The Southeastern Pyrenees has been widely studied as a result of oil exploration. However, the number of boreholes is low and the quality of seismic data is poor due to the structural complexity and the existence of evaporite units (halite and anhydrite) with high density contrasts (Figs. 2B and 3). Therefore, a gravity analysis is integrated with the structural and lithostratigraphic data, becoming a significant tool for validating the geological results. The aim of this work is to show how changes of tectonic plate motions and interactions control the structural evolution of transverse faults and the synchronous thickness and lithological distribution of sedimentary strata in a foreland basin. In order to achieve this, we study the relationship between transverse faults, thickness and lithology distributions through time with the geodynamic evolution of Iberia, Sardinia and Adria. By recording part of the geodynamic history of the Western Mediterranean region, we contribute to the knowledge of transverse extensional faults in foreland basins; specifically on 4-D structural and sedimentary evolution.

\section{GEOLOGICAL SETTING}

\subsection{Geodynamical evolution}

The present-day configuration of the eastern Pyrenees is the result of varying tectonic interactions between Adria, Africa, Eurasia, Iberia, Corsica and Sardinia (Fig. 1B) in five tectonic stages: (1) Late Carboniferous to Permian shearing stage, developing WNW-ESE and NW-SE striking wrench joints and faults (e.g., Vegas and Banda, 1982; Edel et al., 2015); (2) Early Triassic to Early Cretaceous extensional stage, with the reactivation of the previous structures as normal faults (e.g., Le Pichon and Barbier, 1987; Malod and Mauffret, 1990); (3) Late Cretaceous to Early Miocene continental collision stage, with fault inversion and generation of fold-and-thrust belts with foreland basins (e.g., Muñoz, 1992; Lacombe and Jolivet, 2005); (4) Miocene to Pliocene extensional stage, developing normal faults parallel to the eastern coast of Spain and formation 

of extensional basins (e.g., Martí et al., 1992; Gisbert et al., 2019); and (5) present-day compressional stage, with strike-slip and reverse faulting (Jurado, 1996; Goula et al., 1999).

\subsection{Sedimentary record}

The Southeastern Pyrenees sedimentary succession ranges in age from Triassic to Pliocene and overlies a Paleozoic basement of granite and metamorphic rocks (Figs. 2 and 3) (Fleta et al., 1994; Martínez et al., 1994; Muñoz et al., et al., 1994; Vergés et al., 1994). During the early episodes of the continental collision, the sedimentary environments were characterized by nonand shallow- marine deposition. From the Early to Late Eocene, marine facies prevailed through an Atlantic Ocean connection. However, a period of isolation from the sea (not disconnect) from $50 \mathrm{Ma}$ to $46 \mathrm{Ma}$ created conditions for the deposition of marine evaporites (Puigdefàbregas et al., 1986, 1992; Vergés, 1993; Vergés and Burbank, 1996).

For the purpose of this study, the most significant lithostratigraphic units are those of the Late Paleocene as well as the Early and Middle Eocene ages, which form a sedimentary cover up to at least $2600 \mathrm{~m}$ in thickness (Fig. 3). The Late Paleocene to Early Eocene sequence is comprised of carbonates with a middle siliciclastic unit referred to as the Corones Formation. Overlaying this carbonate sequence is a substantial evaporite formation, known as the Serrat Evaporites, which closely marks the boundary between the Early and Middle Eocene. The units deposited before the Serrat Evaporites are referred to herein as the Presalt group. Above these evaporites is the Vallfogona Formation, a unit dominated by siliciclastics and carbonates, and an upper discontinuous second evaporite unit known as the Beuda Gypsum Formation. Collectively, the Vallfogona and Beuda Formations will be referred to as the Suprasalt group. The stratigraphic sequence overlying this group is the Bellmunt sequence, comprised of siliciclastic units (Busquets et al., 1985; Puigdefàbregas et al., 1986, 1992; Gimènez-Montsant and Salas, 1997; Martínez et al., 1997, 2000; Puig et al., 2003; Calvet et al., 2007; Carrillo, 2009; Carrillo et al., 2014).

\subsection{Structural features}

The lithostratigraphic units are divided into two main structural zones; the autochthonous zone to the south and the allochthonous zone to the north. The boundary between these two zones is marked by the Middle to Late Eocene Vallfogona thrust (Figs. 2A and B), a north-dipping frontal thrust (Muñoz et al., 1986; Ramos et al., 2002; Cruset et al., 2018). 
The autochthonous zone contains stratigraphic successions ranging from the Paleozoic (basement) to the Oligocene (Fig. 2). The Ebro and Empordà basins are part of the autochthonous zone and are gently deformed by W-E trending fold-and-thrusts and NNW-SSE and N-S striking faults (Pujadas et al., 1989; Vergés, 1993; Fleta et al., 1994; Martínez et al., 1994; Mató et al., 1996; Martinez et al., 2000; Bello et al., 2008).

The allochthonous zone is divided into two tectonic units known as upper and lower thrust sheets. The upper thrust sheets are located to the most western and eastern parts (Western and Eastern Upper Thrust sheets) of the Southeastern Pyrenees (Fig. 2A), and are formed of sedimentary rocks ranging from Triassic to Late Eocene ages that were displaced between the Paleocene and Late Eocene (e.g., Martínez et al., 1988; Vergés and Martínez, 1988; Pujadas et al., 1989; Vergés, 1993). The lower thrust sheets are characterized by the following subunits: the Cadí thrust sheet, whose major structure is a W-E trending fold known as Ripoll syncline; and the Serrat unit, underlying the Cadí thrust sheet, bounded by both a floor and roof thrust (e.g., Souquet et al., 1975; Muñoz et al., 1986; Martínez et al., 1997; Bello et al., 2008). Several studies have described three stratigraphic locations for regional décollement levels: the lower décollement, situated in the Late Cretaceous-Paleocene rocks (Muñoz et al., 1986; Pujadas et al., 1989); the middle décollement, located in the Early Eocene units (Muñoz et al., 1986; Martínez et al., 1994); and the upper décollement, situated in the Serrat Evaporites (Carrillo et al., 2017).

The Cadí thrust sheet deforms stratigraphic successions ranging from the Paleozoic (basement) to the Oligocene. This structural unit, displaced from the Middle to Late Eocene, is limited to the north by a regional backstop which was active before the Late Eocene (Fig. 2B) (Martínez et al., 1989; Muñoz et al., 1994; Martínez et al., 1994; Ramos et al., 2002). The stratigraphic succession of the structural Serrat unit is incomplete (Vergés, 1993; Bello et al., 2008).

Both the autochthonous and allochthonous zones within the study area are affected by three major east-dipping faults (Fig. 2A) (Martínez et al., 1994; Muñoz et al., 1994; Martínez et al., 2000; Pallí et al., 2011). In the present study, from west to east, these faults are labelled as Western transverse fault (WTF), Central transverse fault (CTF) and Eastern transverse fault (ETF). It has been interpreted that some of these faults were generated as joints during the Late Carboniferous to Permian shearing stage and have been active since the Early Eocene (Estévez, 1970; Santisteban and Taberner, 1979; Martínez et al., 1994; Saula et al., 1994; Goula et al., 1999). 


\subsection{Data set}

194

195

This study uses 24 prestack time-migrated 2-D seismic reflection profiles (Fig. 4A) oriented N-S (perpendicular to the main structural trend) and W-E (parallel to the main structural trend). These profiles were acquired in 1985 by Unión Texas España Inc. and reprocessed by CEPSA. The seismic lines are presented in two-way-time (TWT), having a sample rate of $4 \mathrm{~ms}$ and a record length of $6 \mathrm{~s}$. An estimated average interval velocity of the sedimentary cover of ca. $4850 \mathrm{~m} / \mathrm{s}$ is derived from checkshot data from wells. In order to reflect the relations between transverse faults and thickness and lithology distributions through time, structural and stratigraphic features observed are herein described using seconds in TWT, and meters considering this velocity and applying the velocities shown in Table 1, respectively.

Our study incorporates eight exploration wells (Ampurdan-2, Banyoles-2, Besalú-4, Bestrecà-1, Riudaura-1, Riudaura-2, Serrat-1 and Vallfogona-1 in Fig. 4) which were drilled by different companies (Sociedad de Exploración de Petróleos Españoles S.A., Unión Texas España Inc., Sociedad de Investigación de Petróleos S.A. and Prohidro, S.A.) between 1960 and 1992. Borehole information contains electrical log records (gamma ray, sonic, spontaneous potential, resistivity, bulk density and neutron), dip-meter, vertical seismic profiles (VSP) and around 14.5 $\mathrm{km}$ of combined lithologic records based on cores and cuttings. Additionally, lithological descriptions for the exploration well S-43, as reported by Vidal-Pardal (1954), were considered.

Field descriptions and measurements (stratigraphic and structural features) were collected during field campaigns. This information enabled the updating of previous geological maps (Martínez et al., 1994; Muñoz et al., 1994; Mató et al., 1996; Martínez et al., 2000; Pi et al., 2000) and the generation of eight key lithological sections (sections 1 to 8 ) in the Cadí thrust sheet (Fig. 4B). Lithological information from the Serrat-1 and Bestrecà-1 wells were used to complete two of these sections (sections 2 and 4 in Fig. 4B, respectively).

A detailed gravity survey was conducted with a total of 844 data points measured (Fig. 4A) with a Lacoste-Romberg gravity meter, model G831, and referred to the IGSN-71 through the Spanish Gravity Net. Spatial positioning and height of the stations were obtained from global positioning systems (GPS) and benchmarks with an elevation precision of $\pm 0.1 \mathrm{~m}$. The new gravity measurements were integrated with data from previous surveys (Rivero, 1993; Martinez et al., 1997; Rivero et al., 2002). 
227 Four main and relevant horizons were interpreted from all seismic profiles based on 228 relationships obtained from surface and subsurface stratigraphy, VSP and synthetic seismograms (Fig. 5). These horizons are the following: 1) boundary between the Basement and overlying sedimentary cover; 2) top of the Presalt group; 3) top of the Serrat Evaporites; and 4) top of the Suprasalt group. Another useful surface that provides a stratigraphic control of tectonic events through the time is the top of the Corones Formation, which was used to differentiate the Presalt group into two sub-groups: the Lower Presalt; and the Upper Presalt. In order to match the structural interpretation between the autochthonous and allochthonous zones, 2-D and 3-D surface horizons and fault restorations were performed. According to Carrillo et al. (2017), a shortening of $30 \%$ and $15 \%$ of the Cadí thrust sheet and the structural Serrat unit, respectively, were taking into account for these restorations. In order to highlight fault growth in 3-D and evaluate the impact of the transverse structures on sediment thickness in time and space, isochron and isopach maps (Figs. 6 and 7) and a lithostratigraphic well correlation (Fig. 8A) of the main horizons were generated, based on seismic interpretation and surface mapping. In the case of the Suprasalt group and its overburden (the Bellmunt sequence), interval velocity is well-constrained in the Cadí thurst sheet and the Empordà Basin, and it was converted from time to depth. An average velocity of $3900 \mathrm{~m} / \mathrm{s}$, which corresponds to the average velocity of this group and overburden (Table 1), was used for this conversion. To identify the impact of transverse structures from field evidence, the eight lithological sections were correlated with a W-E orientation (Fig. 8B). Observations from detailed seismic profiles and outcrops (Fig. 9) were incorporated to our study, supporting the structural and stratigraphic interpretations.

251 All the combined gravity data were reduced using the classical formulae of the Bouguer anomaly, where a series of corrections were applied to eliminate the non-geological causes 
were then interpolated by kriging to a $0.5 \mathrm{~km} \times 0.5 \mathrm{~km}$ square grid and contoured. As the Bouguer anomaly map integrates the effect of both long and short wavelength components, the regional factor was removed from the Bouguer anomaly to obtain a residual anomaly map. This last map was assimilated to a second-order surface whose orientation is consistent with the gravity map of the Pyrenees (Casas et al., 1997).

In order to understand residual gravity anomalies and constrain the structural and stratigraphic interpretations, three representative cross-sections were selected and converted from time (in TWT) to depth (Fig. 10). The lithologies and interval velocities used for the conversion are listed in Table 1. The residual gravities of these sections were calculated, obtaining inversion models, and compared to the measured ones (from the residual gravity map). The densities, assumed for the calculated gravities (Table 1), were extracted from previous works (Martínez et al., 1997; Rivero et al., 2001; Carrillo et al., 2014).

\section{Basin and regional framework}

The isopach maps were integrated with the stratigraphic correlations and results of the detailed seismic and outcrop interpretations as well as the results documented in previous works to produce three novel paleogeographic maps (Fig. 11). These maps correspond to tectonosedimentary stage models. Each map shows structural features and depositional lithofacies, integrating both the autochthonous and allochthonous zones and accounting for the forementioned shortenings established by Carrillo et al. (2017).

The paleogeographic maps were compared with regional tectonic studies to identify relationships between thickness and lithological distributions of sedimentary strata, influenced by transverse faults, and tectonic plate processes, such as Iberia and Sardinia. To illustrate these relationships, we constructed a trans-orogenic (350 km long) cross-section at the scale of the lithosphere (Fig. 12). This section shows the geodynamic evolution of Iberia and Sardinia during part of the continental collision stage (Late Paleocene to Middle Eocene), based on previous works, and the tectono-sedimentary features obtained in the present study. Finally, in order to highlight the contribution of our work, a comparison between the tectono-sedimentary evolution of the studied transverse faults and similar structures in other regions was achieved.

\section{STRUCTURE}


In the present study, it is observed that the major transverse structures affect the Basement and sedimentary succession ranging from the Presalt group to the Bellmunt sequence in both the autochthonous and allochthonous zones with a high of at least 2.00 s TWT (ca. 4850 m) (Figs. 4B and 5). In the case of the WTF, the upper fault tip is located up to the lower part of the Bellmunt sequence (Figs. 5A and B). These faults divide the study area into structural blocks (Fig. 6), with footwalls and hanging walls as well as secondary structures which are irrelevant in the present study. In order to understand fault growth and thickness variations through the time, a description of the present-day structural features is presented in the following sections.

\subsection{Transverse faults}

\section{Western Transverse Fault (WTF)}

In the Ebro Basin, the WTF is located eastward of the Riudaura-1 well (Fig. 4B). Here, this structure has a maximum throw of $0.45 \mathrm{~s}$ (ca. $1100 \mathrm{~m}$ ) at the top Basement with a normal geometry (Fig. 5A). Based on a 3-D geometry of the seismic horizons, it is observed that this structure continues north below the Vallfogona thrust with a maximum throw at the top Basement of $0.83 \mathrm{~s}$ (ca. $2010 \mathrm{~m}$ ) and a normal geometry (Fig. 6A). In the autochthonous zone, the length of the WTF is at least of $15 \mathrm{~km}$.

In the Cadí thrust sheet, a significant NNW-SSE fault, exposed in the northwest region of the study area (Fig. 4B), has been described in previous works (Muñoz et al., 1994; Martínez et al., 2015). Based on restorations, this fault links to the WTF in the autochthonous zone. Here, this fault has a reverse and dextral movement with a maximum throw at the top Serrat Evaporites of $0.37 \mathrm{~s}$ (ca. $900 \mathrm{~m}$ ) (Fig. 5E). To the southeast of Serrat-1, near the subsurface axis of the Ripoll syncline, the WTF is theorized to link to blind faults displaying NW-SE strikes (Fig. 6B) with normal displacements and throws at the top Serrat Evaporites of up to $0.13 \mathrm{~s} \mathrm{(ca.} 315 \mathrm{~m}$ ) (Figs. $5 B$ and $D)$. The length of the WTF through the Cadí thrust sheet is at least of $12 \mathrm{~km}$.

\section{Central Transverse Fault (CTF)}

In a similar manner to the WTF, the CTF in the allochthonous zone fits with an ENE-dipping fault below the Vallfogona thrust (Figs. 5D and 6A). This second fault corresponds to the CTF in the autochthonous zone having a normal geometry and throw at the top Basement of up to $0.54 \mathrm{~s}$ 
316 (ca. 1310), which decreases northward. In the autochthonous zone, the length of the CTF is at 317 least of $5 \mathrm{~km}$.

In the Cadí thrust sheet, the CTF is superimposed by a NNW-SSE trending anticline with a length of at least of $12 \mathrm{~km}$ (Figs. 5B and 6B). This anticline affects the stratigraphic successions ranging between the Presalt group and the Bellmunt sequence, including the sequences of the structural Serrat unit. Geometrically, the fold has a low curvature and its west limb is steeper than the east limb. In the western limb, the CTF is observed with a reverse movement and a throw at the top Serrat Evaporites of $0.15 \mathrm{~s}$ (ca. $360 \mathrm{~m}$ ). In the northern part of the Cadí thrust sheet, the CTF steps westward and displays a normal kinematic sense (Figs. 5D and E).

In the northern part of the ETF, the structure displays a reverse displacement of horizons in the autochthonous zone with a throw at the top Basement of $0.58 \mathrm{~s}$ (ca. $1410 \mathrm{~m}$ ) (Fig. 6A). To the south, this fault has a normal geometry with a maximum throw of $0.88 \mathrm{~s}$ (ca. $2135 \mathrm{~m}$ ) (Fig. 5C). However, this throw decreases to $0.39 \mathrm{~s}(\mathrm{ca} .950 \mathrm{~m}$ ) in the most southern part. The ETF has a length of at least of $16 \mathrm{~km}$.

\subsection{Structural blocks}

All the structural blocks in the study area contain low relief (<0.13 s depth; ca. $315 \mathrm{~m}$ ) basement folds and faults. In the autochthonous zone, the footwall block of the WTF is mainly characterized by a NW-verging monocline (Fig 6A). By contrast, both the footwall and hanging wall blocks of the CTF present W-verging half-grabens. The hanging wall block of the ETF contains a S-verging graben-monocline and an E-W trending blind fold-thrust, extending almost until the ETF (Fig. 5C).

In the Cadí thrust sheet, the footwall of the WTF shows the geometry of the Ripoll syncline with a horizontal fold hinge (Fig. 6B). Between the WTF and the CTF, the Serrat Evaporites are affected by a NNW-SEE trending depression (Fig. 5D). Moreover, in the structural Serrat unit, an evaporite dome is noted in the northeastern sector of the related block. From the CTF to the ETF, two structural areas are recognized: the west side with a depression; and the east side with a high. 


\section{THICKNESS AND LITHOLOGICAL DISTRIBUTION}

348

349

350

351

352

353

354

355

356

357

358

359

360

361

362

363

364

365

366

367

368

369

370

371

372

373

374

375

376

377

Thickness and lithology variations of the lithostratigraphic units are identified in both the autochthonous and allochthonous zones (Fig. 5). These distributions vary markedly adjacent to the transverse faults as well as the low relief basement folds and faults (Figs. 7 and 8). The variations are described separately for the Presalt group, the Serrat Evaporties and the Suprasalt group.

\subsection{Presalt group}

In the autochthonous zone, the thickness of the Presalt group increases across the footwalls to the hanging walls of the transverse faults (Fig. 7A). In the footwall of the WTF, a thickening of this group to the northwestern sector is observed, varying from $0.14 \mathrm{~s}$ to $0.32 \mathrm{~s}$ (ca. 370 to 840 m) thick. In the footwall of the CTF, a depocenter is recognized adjacent to the WTF. This depocenter has a maximum thickness of $0.51 \mathrm{~s}$ (ca. 1340), which dramatically decreases southward to $0.18 \mathrm{~s}$ where the throw of the WTF is less (Fig. 6A). Toward the CTF, the thickness is reduced to $0.10 \mathrm{~s}$ (ca. $260 \mathrm{~m}$ ). In the hanging wall of the CTF, the Presalt strata thickness is $0.39 \mathrm{~s} \mathrm{(ca.} 1020 \mathrm{~m}$ ), which decreases slightly to the center of the block. In the northeastern sector of this block, a depocenter of up to $0.38 \mathrm{~s}$ thick is noted on an axial trace of a SW-NE trending basement syncline. In the southern sector, the Ampurdan-2 well crossed the enire Presalt Group (441 m thick), on a structural high (Fig. 8A). In the hanging wall of the ETF, from outcrop the Presalt thickness is $2200 \mathrm{~m}$ (stratigraphic section 8, Fig. 8B). The greatest subsurface thickness in the study area (up to $1.10 \mathrm{~s} ; \mathrm{ca} .2670 \mathrm{~m}$ ) is observed within the northern and central sectors of this block (Figs. 5C and 7A). However, this thickness estimate is affected by structural thickening (up to ca. 30\%), related to a blind fold-thrust (Fig. 5C). The thickness decreases towards the southern sector of the block, where the throw of the ETF is less (Fig. 6A).

In the Cadí thrust sheet, the thickness of the Lower Presalt increases greatly across the CTF and ETF from the footwall to hanging wall (Fig. 8B). The same occurs for the Upper Presalt across the ETF; conversely, the thickness of the Upper Presalt decreases across the CTF. The structural block between the WTF and the CTF displays westward thickening of the Presalt group from 1340 to $1980 \mathrm{~m}$, and 1110 to $1340 \mathrm{~m}$ for the structural block between the CTF and ETF.

The thinnest ( $<500 \mathrm{~m}$ thick) successions of the Presalt group are dominated by about $80 \%$ of limestones and $20 \%$ of marls and sandstone in both the Ebro and Empordà basins and the 
allochthonous zone (Fig. 8). On the contrary, the thickest (>500 m thick) successions are formed of $50 \%$ marls and shales and $50 \%$ of limestones and sandstones.

\subsection{Serrat Evaporites}

In the autochthonous zone, the thickness of the Serrat Evaporites increases across the footwalls to hanging walls of the CTF and in the southern part of the ETF (Figs. 5B and 7B). In the footwall block of the WTF, the average thickness of the Serrat Evaporites is $0.20 \mathrm{~s}$ (ca. $520 \mathrm{~m}$ ). However, the thickness increases to $0.27 \mathrm{~s}$ along the Serrat Evaporites-Vallfogona thrust contact, probably due to structural thickening (salt tectonics). The footwall of the CTF shows a peculiar E-W trending "salt" wall with thicknesses up to $0.34 \mathrm{~s}$ (ca. $885 \mathrm{~m}$ ) below the Vallfogona thrust (Fig. $6 A$ ). To the north and south of this wall, the evaporitic succession is thinnest (Figs. 5B and D) with, locally, low values of $0.05 \mathrm{~s}$ (ca. $130 \mathrm{~m}$ ) ("salt" welds). In the footwall block of the ETF, the Serrat Evaporites unit thickens from $0.1 \mathrm{~s} \mathrm{(ca.} 260 \mathrm{~m}$ ) thick in the central region to $0.25 \mathrm{~s}$ (ca. $650 \mathrm{~m}$ ) thick towards the CTF. In the southeastern sector of this block, near the contact between the Serrat Evaporites and the Vallfogona thrust, the thickness is around $0.29 \mathrm{~s} \mathrm{(ca.} 750 \mathrm{~m}$ ). However, eastward of the Besalú-4 well, the thickness decreases to $0.07 \mathrm{~s} \mathrm{(ca.} 180 \mathrm{~m}$ ) on a basement high (Fig. 5C). The unit thicknesses in the Ampurdan-2, S-43 and Banyoles-2 wells are 240, 160 and $220 \mathrm{~m}$, respectively (Fig. 8A). In the hanging wall of the ETF, the evaporites are not recognized outcropping northward (section 8 in Fig. 8B), where the ETF has a reverse geometry (Fig. 6A). On the other hand, to the south, a thin (0.07 s thick) succession of the Serrat Evaporites is recognized with erosional truncations (Fig. 9A). This succession increases in thickness southward, up to $0.37 \mathrm{~s}$ (ca. $960 \mathrm{~m}$ ) thick, where a significant depocenter is present.

In the allochthonous zone, different areas of prominent thickness of the Serrat Evaporites are observed (Figs. 5B and D). In the Cadí thrust sheet, these areas are located in the north limb of the Ripoll syncline, westward between the WTF and CTF, with at least $0.17 \mathrm{~s}(300 \mathrm{~m}$ thick; Fig. $8 \mathrm{~B}$ ), and in the eastern part between the CTF and ETF, at least $0.20 \mathrm{~s}$ (ca. $520 \mathrm{~m}$ ) thick. By contrast, thin (<100 $\mathrm{m}$ thick) successions of the Serrat Evaporites are recognized eastward of the footwalls related to the WTF and CTF. In the structural Serrat unit, an area with a marked thickness of at least $0.78 \mathrm{~s}$ (ca. $2030 \mathrm{~m}$ ) is observed on the footwall of the WTF (Fig. 5E). This thickness decreases progressively in the footwall of the CTF. In the anticline superimposing this structure, another area with a significant thickness of at least $0.51 \mathrm{~s}$ (ca. $1330 \mathrm{~m}$ ) is noted (Fig. $5 B)$. 
410 The lithology distribution of the Serrat Evaporites has the following features: 1) in the Ebro Basin,

411 anhydrite and carbonate layers dominate the structural highs (Figs. 8A); 2) in the structural

412 Serrat unit, in agreement with Carrillo et al. (2014), anhydrite and shale prevail between the

413 WTF and CTF in the north limb of the Ripoll syncline; and 3) in the Cadí thrust sheet, successions 414 of anhydrite with a minor content of salt are present in the footwalls of the transverse faults 415 (Vallfogona-1 well; Fig. 5B in Carrillo et al., 2017), while salt with minor content of anhydrite are 416 observed in the hanging walls (Serrat-1 well; section 2 in Fig. 8B).

\subsection{Suprasalt group}

In the autochthonous zone, the thickness of the Suprasalt group increases from the footwall to hanging wall across both the WTF and ETF (Figs. 5A and 7C). In the footwall of the WTF, $100 \mathrm{~m}$ of the Suprasalt group were measured in the Riudaura-1 well. Adjacent to the WTF hanging wall, a thickness up to $0.36 \mathrm{~s}(\mathrm{ca} .860 \mathrm{~m}$ ) is identified (Fig. 5B). Just east of the CTF, within the CTF hanging wall, this group reaches at least $0.25 \mathrm{~s}(\mathrm{ca} .600 \mathrm{~m})$. This thickness decreases eastward, adjacent to the ETF, ranging from 80 to 150 m thick (Fig. 8A). In the hanging wall of the ETF, the Suprasalt group displays up to $220 \mathrm{~m}$ thick in the northern part (Fig. 8B). There, in some seismic profiles, reflectors corresponding to the Suprasalt group truncate the Serrat Evaporites (Fig. 9A). In the southeastern part of the ETF hanging wall, this group has a depocenter of up to $0.20 \mathrm{~s}$ (ca. $480 \mathrm{~m}$ ) thick (Fig. 5C).

On the northern limb of the Ripoll syncline in the Cadí thrust sheet, the thickness of the Suprasalt group decreases from the footwalls to hanging walls across the WTF and CTF (Fig. 8B). By contrast, the thickness increases across the faults on the synclinal southern limb (Fig. 9B). Therefore, in the northeastern and southwestern parts of the related structural blocks, depocenters ranging from 500 to $1000 \mathrm{~m}$ thick for the Suprasalt group are identified (Fig. 7C). While, in the northwestern and southeastern parts, the thickness decreases abruptly with values lower than $500 \mathrm{~m}$. Seismic reflectors of the Suprasalt group onlaping the Serrat Evaporites are recognized in the southwestern depocenter toward the transverse faults (Fig. 9B).

The thinnest (up to 250 m thick) successions of the Suprasalt group are mainly dominated by carbonate, siltstone and sulphate layers (Fig. 8). These successions are identified in the Ebro and Empordà basins as well as the local eastern part of the Cadí thrust sheet. By contrast, the thickest (>250 m thick) successions are formed of siltstone, sandstone and sulphate layers. 


\section{GRAVITY CONSTRAINTS}

443 In the residual gravity map, values ranges from 13 to $-10 \mathrm{mGal}$. A series of significant anomalies 444 and variations on residual gravity with NNW-SSE, NW-SE and NE-SW directions are observed. In 445 the inversion models (Fig. 10), part of these variations are located around the transverse faults. 446 The models are referred to herein as "Central model" (Fig. 10A), related to Figure 5B, "Eastern model" (Fig. 10B), for Figure 5C, and "Northern model" (Fig. 10C), linked to Figure 5D. While small variations in the thicknesses and densities used in the models can render similar residual gravity trends, no alternative structural interpretation has been found that matches the information available.

451

\subsection{Central model}

In the Central model (Fig. 10A), a positive residual anomaly of up to $4 \mathrm{mGal}$ is identified in the westernmost sector. We relate this anomaly to the existence of a $1.8 \mathrm{~km}$ thick deposit of pure anhydrite ( $>80 \%$ in anhydrite content with an average density of $2.90 \mathrm{~g} / \mathrm{cm}^{3}$ ) of the Serrat Evaporites, forming part of a relative thin (up to $3.0 \mathrm{~km}$ thick) sedimentary cover. Residual gravity decreases to $-1 \mathrm{mGal}$ at the axis of the Ripoll syncline, indicating a thickening (up to 4.1 $\mathrm{km}$ ) of this sedimentary cover and thinning of the anhydrite deposit. Residual gravity increases up to $1 \mathrm{mGal}$ at the CTF, signifying a thin sedimentary cover with thickening of the anhydrite deposit. From the CTF towards the Vallfogona thrust, residual gravity initially decreases to -1 $\mathrm{mGal}$, however, continuing east it increases to a positive anomaly of up to $5 \mathrm{mGal}$. The negative value is attributed to a salt body $\left(2.10 \mathrm{~g} / \mathrm{cm}^{3}\right)$ up to $0.8 \mathrm{~km}$ thick in the structural Serrat unit. The positive anomaly is associated with thickening (up to $2.1 \mathrm{~km}$ ) of the anhydrite deposit within a thin (up to $2.5 \mathrm{~km}$ thick) sedimentary cover. Eastward of the Vallfogona thrust, a negative residual anomaly of up to $-8 \mathrm{mGal}$ is recognized. We relate this anomaly to the following three features: 1$)$ presence of the thinnest $(0.7 \mathrm{~km}$ thick) sedimentary cover; 2$)$ low thickness $(<0.4$ $\mathrm{km}$ thick) of the anhydrite deposit; and 3) thickening of siliciclastics $\left(2.45-2.60 \mathrm{~g} / \mathrm{cm}^{3}\right)$ of the Bellmunt sequence.

\subsection{Eastern model}

In the Eastern model (Fig. 10B), between the Ampurdan-2 well and the intersection point with Figure $10 \mathrm{~A}$, the residual gravity gently reduces from -7 to $-9 \mathrm{mGal}$. These negative values are associated with the same three features listed for the easternmost section of the Central model. These facts, combined with the Ampurdan-2 lithologic descriptions (Fig. 8A), suggest a change 
of the basement lithology, from a high to low concentration of schist and increment of granite ( 2.72 and $2.64 \mathrm{~g} / \mathrm{cm}^{3}$, respectively). From the Central model intersection point to the hanging wall of the ETF, the residual gravity rises abruptly up to $-3 \mathrm{mGal}$. This change is mainly due to two features: 1) a variation in both lithology and thickness of the Serrat Evaporites, from anhydrite and carbonate $\left(2.83 \mathrm{~g} / \mathrm{cm}^{3}\right)$ at $\sim 0.4 \mathrm{~km}$ thick to pure anhydrite at $\sim 1.0 \mathrm{~km}$ thick; and 2) a variation in lithology of the Basement, from granite to schist. Towards the northeastern end of the Eastern model, residual gravity increases up to $-2 \mathrm{mGal}$ due to reduced thickness of the siliciclastic Bellmunt sequence.

\subsection{Northern model}

In the Northern model (Fig. 10C), from southeast to northwest, the residual gravity increases from 0 to $4 \mathrm{mGal}$ in a NW direction. This positive trend is attributed to the existence of a thick deposit $(1.0 \mathrm{~km})$ of pure anhydrite in the frontal part of the structural Serrat unit. Passing northeast from the Cadi thrust sheet to the CTF, residual gravity reduces to $-8 \mathrm{mGal}$, indicating a decrease in anhydrite content in the passage towards a more shale and salt prone section in the structural Serrat unit. A salt dome was added to the model to explain the lowest residual gravity point. Continuing northeast, the residual gravity rises to $-5 \mathrm{mGal}$, suggesting a thick deposit $(1.2 \mathrm{~km})$ of pure anhydrite below the Vallfogona thrust. Residual gravity values then drop to up to $-8 \mathrm{mGal}$, which is associated with a reduction in anhydrite thickness.

\section{TECTONO-SEDIMENTARY EVOLUTION OF THE TRANSVERSE FAULTS}

We propose three paleogeographic maps for the Late Paleocene to Middle Eocene tectonosedimentary evolution of the main transverse faults addressed in this study (WTF, CTF and ETF) (Fig. 11). In addition, these maps include the evolution of N, NNE, NW and NE dipping faults also identified in the study area. The $\mathrm{N}$ and NNE dipping faults, located in the northern and northeastern parts of the study area, have been interpreted in previous works (Martínez et al., 1989; Pujadas et al., 1989). The maps are synchronous to the sedimentation of the Presalt group, Serrat Evaporites and Suprasalt group, corresponding to the following sedimentary stages: Stage 1 (Fig. 11A), Late Paleocene to Early Eocene (57 to $51 \mathrm{Ma}$ ); Stage 2 (Fig. 11B), Early to Middle Eocene (51 to $49 \mathrm{Ma}$ ); and Stage 3 (Fig. 11C), Middle Eocene (49 to 44). The maps emphasize: (i) basin topography of the structural blocks; and (ii) the relationships between this topography, lithology, and thickness. 
Thickening of the Presalt strata across the footwalls to the hanging walls of the transverse faults 510 (Figs. 7A and 8) suggests that these structures worked as normal faults during Stage 1 (Fig. 11A). 511 This fact is in agreement with Estévez (1970) for the ETF. Southward thinning of the strata along these structures indicates changes in throw.

Based on the relationships between thickness distribution, as controlled by extensional transverse faulting, and lithology of the Presalt strata (Figs. 7A and 8), the following tectonosedimentary features are interpreted for the present stage: limestones, deposited in structural highs (footwalls); and shales and marls, deposited in structural depressions (hanging walls) (Fig. 11A). In agreement with previous works (Martínez et al., 1988; Gimènez-Montsant and Salas, 1997), the shale and marl correspond to deep platform environments, and the limestone to shallow platform. In turn, the present study interprets that NNW-SSE depositionalenvironmental belts were formed within each of the structural blocks, characterized by deep platform environments to the west and shallow platform environments to the east. According to Gimènez-Montsant and Salas (1997), the northeastern part of the study area was a shallow detrital environment, attributed to a delta plain deposited on an uplifted eastern margin.

\subsection{Stage 2: Early to Middle Eocene (51 to $49 \mathrm{Ma}$ )}

During the second stage, a westward thickening of the Serrat Evaporites between the WTF and CTF in the Cadí thrust sheet (Fig. 8B) suggests that normal faulting was active in the northern portion of the WTF (Fig. 11B). Determining topographic and tectonic configuration along the southern portion of the WTF is problematic, due to the high degree of present-day deformation observed for the Serrat Evaporites along this structure (Fig. 7B). However, normal faulting is also proposed for the southern sectors of the CTF and ETF as they demonstrate the expected stratigraphic thickening across the footwall to the hanging wall blocks in the autochthonous zone (Fig. 10). On the other hand, the northward thinning along the ETF hanging wall and the unconformities within the Serrat Evaporites (Fig. 9A) indicate contractional faulting along the northern portion of the ETF. In the case of the salt dome modeled in the structural Serrat unit between the WTF and CTF (Fig. 10C), we interpret that this dome was transported from the prekinematic hanging wall of the CTF to the present-day allochthonous zone. 
540 for the present stage: anhydrite, limestone and dolostone, accumulated in structural highs; and 541 halite or shale, deposited in structural depressions (Fig. 11B). In agreement with Carrillo et al. 542 (2014), the anhydrite, carbonate and dolostone correspond to sulphate-carbonate shelves, pure 543 anhydrite to selenitic wedges or basins, and the halite to salt deep basin. Therefore, in the 544 present paper, it is interpreted that selenitic and salt deep basins were mainly concentrated along the hanging walls adjacent to the active transverse extensional faults.

\subsection{Stage 3: Middle Eocene ( 49 to $44 \mathrm{Ma}$ )}

Thickening of the Suprasalt strata across the footwalls to the hanging walls of the transverse faults in the autochthonous zone and the southern part of the Cadí thrust sheet (Fig. 7C) suggests that the southern portion of these structures worked as normal faults during Stage 3 (Fig. 11C). However, northern and northwestern thinning of the units within the same blocks (Fig. 8B) indicate contractional faulting along the northern portions of the transverse structures. In the case of the ETF, the erosional truncations of the Suprasalt group on the Serrat Evaporites in the northern sector of the Empordà Basin (Fig. 9A) suggest that the contractional zone migrated southward from that in Stage 2, and was located further south than the contractional zones of the WTF and CTF in Stage 3.

557 Based on the relationships between lithology of the Suprasalt strata (Fig. 8) and thickness 558 distribution, as controlled by transverse faulting, the following tectono-sedimentary features 559 are interpreted for the current stage: carbonate, siltstone and sulphate layers, deposited in 560 structural highs (footwalls); and siltstone, sandstone and sulphate layers, deposited in structural depressions (hanging walls) (Fig. 11A). In agreement with previous works (Costa, 1989; Carrillo et al., 2014), the carbonate, siltstone and sulphate layers correspond to shelves, and the siltstone, sandstone and sulphate layers to slope/submarine fans. Thus, in the present study, it is interpreted that slope/submarine fans concentrated in the northern and southwestern parts of the structural blocks.

\section{DISCUSSION}


571 The results described above, collaborated with descriptions of eastern Pyrenees tectonic 572 processes, opens a discussion on how changes in tectonic plate motions and interactions control 573 the structural evolution of transverse faults and the synchronous thickness and lithological 574 distribution of sedimentary strata in a foreland basin.

575 The structural evolution of the transverse faults and the synchronous thickness and lithology 576 distribution across these structures, as observed in the present work (Fig. 11), indicates a 577 progressive change from stretching to contractional mechanisms migrating from north to south 578 along faults and east to west across structural blocks. This change occurred during the ending of 579 the Early Eocene (ca. $51 \mathrm{Ma}$ ) as a response of tectonic processes affecting Iberia and Sardinia. 580 To evaluate this response, we present a cross-section (Fig. 12) which assumes the following two 581 points: 1) Sardinia and Corsica were an independent continental block, not a part of Iberia; and 582 2) during the Eocene, the southernmost part of Sardinia was tectonically interacting with the 583 easternmost part of Iberia. These points are in agreement with previous works (Horner and 584 Lowrie, 1981; Lacombe and Jolivet, 2005; Andreani et al., 2010; Advokaat et al., 2014; Bestani 585 et al., 2016). The present-day thickness of the lberian continental crust is characterized by eastward thinning, from ca. $45 \mathrm{~km}$ in the central Pyrenees to ca. $20 \mathrm{~km}$ in the Empordà Basin (Chevrot et al., 2018). This thinning is due to the Miocene to Pliocene extensional stage, which displaced Sardinia with a counter-clockwise rotation to the present-day position (e.g., Roca et al., 1999). The two continental blocks of Sardinia and Corsica have a maximum crustal thickness of $34 \mathrm{~km}$ (Egger et al., 1988), and they thin up to $25 \mathrm{~km}$ along the margins (Gailler et al., 2009; Prada et al., 2013). According to Bestani et al. (2016), the southeastern part of Eurasia and Corsica had maximum crustal thickness of $60 \mathrm{~km}$ during the Eocene. Therefore, in the present study, it is assumed that during the same epoch, the easternmost part of the Iberian as well as the Sardinian crust would have been thicker than the present-day, between 45 and $60 \mathrm{~km}$. According to previous works (Malusà et al., 2016; Macchiavelli et al., 2017), two tectonic phases related to motions of Adria and Iberia, with respect to Eurasia, are distinguished from the Late Paleocene to Middle Eocene. These phases are illustrated in Figure 12, where the first phase takes place from 57 to $51 \mathrm{Ma}$ and a second phase between 51 and $44 \mathrm{Ma}$. The relationships between these phases and the tectono-sedimentary evolution of the Southeastern Pyrenees and southern part of Sardinia are discussed below. 
During the first phase, Iberia was moving east and Adria to the west, relative to Eurasia (Malusà et al., 2016; Macchiavelli et al., 2017). Consequently, it is known that during the Early Eocene, Sardinia and Corsica were overthrusting Iberia and Eurasia forming an active N-S striking mountain range (Fig. 12A) (Lacombe and Jolivet, 2005; Andreani et al., 2010; Bestani et al., 2016). It is assumed in the present study that the boundary between the Iberian plate and the Sardinian block was marked by a main thrust known as the present-day Northern Balearic Fracture Zone (NBFZ; Fig. 1A).

In the Sardinian block, we identify three domains which prevailed during the first phase, from west to east: 1) a high-relief thrust system, verging to the east and deforming basement units and a sedimentary Mesozoic cover; 2) a Tethyan-influenced marine piggy-back basin; and 3) a basement high with a sedimentary Mesozoic cover (Fig. 12A). Apatite U-Th/He (AHe) with cooling ages between 80 and $57 \mathrm{Ma}$ in the southernmost part of Sardinia, analyzed by Malusà et al. (2016), and E-verging thrusts affecting Mesozoic series (Barca and Costamagna, 1997), supports the existence of the first domain. To the north, previous works (Carmignani et al., 2004; Costamagna and Schäfer, 2017) recognize Early Eocene shallow marine carbonate deposits indicating the influence from the Tethys sea within the second domain. In the central-east of Sardinia, thermochronological interpretations by Zattin et al. (2008) suggest uplifting from 140 Ma to Oligocene, supporting the basement high of the last domain.

In the Iberian plate, we also recognize three domains during the first phase, from east to west: 1) a high-relief W-verging thrust system, deforming basement units and a sedimentary Mesozoic cover; 2) an Atlantic-influence marine foreland basin controlled by N-S striking normal faults; and 3) a low-relief thrust system, verging to the east and involving sedimentary Mesozoic cover (Fig. 12A). West verging structures involving metamorphic and Mesozoic units have been welldocumented (e.g., Fleta et al., 1994; Carreras, 2001; Druguet et al., 2001), supporting the existence of the first domain. We propose that during the first phase a load and lithospheric flexure in the easternmost part of the Iberian plate developed due to the Sardinian overthrusting. Consequently, activation of E-dipping normal faults for both pre- and early orogenic structures were generated, giving rise to thick/deep and thin/shallow carbonate platform deposits across the hanging walls and footwalls of the transverse structures. Also, a forebulge transversal to an active W-E Pyrenean range was formed in the central part of this basin. The paleogeographic features of our Stage 1 (Fig. 11A) are consistent with this proposal. Apatite fissions tracks (AFT) with cooling ages between 59 and $48 \mathrm{Ma}$ for Mesozoic units in the Western Upper Thrust Sheet (Fig. 2A), documented in Rushlow et al. (2013), suggest the lowrelief in the last Iberian domain. 
During the second phase, relative to Eurasia, Iberia and Adria were displacing to the northwest and north, respectively (Fig. 12B) (Malusà et al., 2016; Macchiavelli et al., 2017). Therefore, a transpressive stress regimen dominated between Iberia and Sardinia (Lacombe and Jolivet, 2005; Andreani et al., 2010), potentially through the NBFZ.

In the Sardinian block, molasse facies (alluvial fan and fluvial systems) in the south, documented 645 by Costamagna and Schäfer (2017) with a Middle Eocene age, suggest that the uplifting of the 646 Sardinian high-relief thrust system persisted, and the piggy-back basin disconnected from the 647 Tethys sea (Fig. 12B). In the basement high domain, Middle Eocene deformation affected the Mesozoic cover with minor fold-and-thrusts (Arragoni et al., 2016).

In the Iberian plate, syn-orogenic conglomerates in the frontal parts of the Eastern and Western upper thrust sheets (Martínez et al., 1988; Pi et al., 1997), indicate that the high and low relief thrust systems continued their uplifting to at least the Late Eocene (Fig. 12B). A change from extensional to contractional kinematic of the transverse faults occurred in the northern part of the foreland basin, giving rise to thin/shelf deposits in the hanging walls as it is observed in our Stages 2 and 3 (Figs. 11B and C). By contrast, thick/submarine fan deposits were generated in the footwalls. We interpret that the structural change from extensional to contractional was due to the new displacement of Iberia to the northwest, where the active Pyrenan chain was acting as backstop. The east to west migration of contraction is consistent with the existence of Eulerian counter-clockwise poles to the central part of Iberia (Tavani et al., 2018 and referred herein). The transition between the first and second phases is also marked by a lithological change from carbonates (Presalt Group) to evaporites (Serrat Evaporites and the Suprasalt Group) and siliciclastics (Suprasalt Group) in the foreland basin suggesting a tectonic control on basin marine restriction and sedimentary conditions.

\subsection{Comparisons with other regions}

Geometries and stratigraphic variations through transverse faulting in foreland basins have been reported in the central and southern Apennines (Doglioni, 1995; Tavani et al., 2015), the Eastern Maghrebides (Torelli et al., 1998; Bianca et al., 1999; Billi et al., 2006; Gutscher et al., 2015) and the Carpathian Bend Zone (Tărăpoancă et al., 2003). All these examples acted with two stages of different stress direction: a first extensional stage; and a subsequently reverse and/or strike- 
670 slip motion (e.g., Tărăpoancă et al., 2003; Tavani et al., 2015; Gutscher et al., 2015). The main tectonic and stratigraphic features of these foreland basins are highlighted and compared to our case study.

In the Apennines, Tavani et al. (2015) have provided a kinematic evolution of a fault system transversal to a paleo-subducting front. The same authors have interpreted that the transverse extensional faulting was attributed as a response of a syncline arching and flexure of a subducted plate forming a non-cylindrical forebulge. The sedimentary succession deposited during the motion of the fault system is only formed of siliciclastics. Fault-throws at the pre-faulting horizons and synchronous stratigraphic thickness have not been reported in the Apennines.

In the Carphatian Bend Zone, Tărăpoancă et al. (2006) have shown foreland deposits within hanging walls of faults transversal to a thrust front. This work displays thickness variations, although, it is based only on seismic data.

In the Eastern Maghrebides, Torelli et al. (1998) have recognized a stratigraphic record deposited coevally with normal faulting transversal to the Maghrebian Thrust Belt. A forebulge, transversal to this front, has also been identified (Torelli et al., 1998; Bianca et al., 1999; Billi et al., 2006). According to Billi et al. (2006), the normal faults were developed due to a flexure of a subducted plate associated with a lateral loading effect by a growing accretionary wedge. Thickness variations in 2D across the faults and a diversity of lithologies have been recognized in the related foreland basin (Hyblean basin; Torelli et al., 1998). However, this information is based on off-shore subsurface data.

From a tectonic point of view, we consider that the generation of the transverse extensional faults in the Eastern Maghrebides (described above) is analogue to the studied faults in the present work. Furthermore, again similarly to the Eastern Maghrebides, the Southeastern Pyrenees underwent lateral loading from an additional orogenic salient (the Sardinian block; Fig. 12A) forming flexural extension. By contrast, the cases from the Apennines and the Carphatian Bend Zone were controlled by a single orogenic salient in an along-strike stretching setting.

Our case study in the Southeastern Pyrenees provides the complete structural, stratigraphic and lithologic features related to a tectono-sedimentary evolution of transverse extensional faults in a compressional regimen. Here, we have an on-shore case which is supported by field, seismic and well data. Moreover, thickness distribution patterns and lithology variations (carbonates, evaporites and siliciclastics) during the structural evolution are recognized. In Tavani et al. (2015), the orientation of the fault-dips and the impact of the structural evolution on thickness 
lithology variations and structural evolution of transverse faults, supported by field and/or well evidences, have not been provided. In the Eastern Maghrebides, field examples have not been reported yet. All of these remaining features make the Southeastern Pyrenees an exceptional area to understand the 4-D structural and sedimentary evolution of transverse extensional faults in foreland basins.

\section{CONCLUSIONS}

Based on the analysis of Late Paleocene to Middle Eocene sedimentation patterns of the Southeastern Pyrenees and data documented in previous works, the principal conclusions of this study, are:

1) Two main tectono-sedimentary phases can be distinguished: 1) first phase with deep and shallow marine carbonate accumulation controlled by extensional faulting, transverse to an active Pyrenean chain, synchronoulsy to east displacement of Iberia and frontal collision of this plate with Sardinia (ca. 57 to $51 \mathrm{Ma}$ ); and second phase with marine evaporitic and siliciclastic deposition influenced by re-activation of the transverse structures as contractional faults coevally to northwest motion of Iberia and transpressive stress regimen between Iberia and Sardinia (ca. 51 to $44 \mathrm{Ma}$ ).

2) Our study reveals how the tectono-sedimentary evolution of transverse faults in foreland basins record changes on motions and interactions of tectonic plates and continental blocks. These changes have an influence on structural evolution of transverse faults and the synchronous thickness and lithology distributions. Moreover, the present work highlights the importance to analyze relationships between stratigraphic sequences, affected by transverse faults in orogenic chains, and tectonic processes as key to understanding kinematic histories of complex compressional and/or subduction zones.

3) The tectonic origin of transverse extensional faults in the Southeastern Pyrenees is similar to the Eastern Maghrebides where a lateral loading occurred presenting two orogenic salients. The Southeastern Pyrenees is an exceptional area to understand the structural evolution of transverse extensional faults active by bending foreland lithosphere. It provides field and subsurface evidences where thickness and lithology distributions are observed through the time as a response to the evolution of these 
structures. Moreover, the Late Paleocene to Middle Eocene stratigraphic record of this easternmost part of Iberia contributes to better understanding the complex geodynamic history of the Western Mediterranean region.

\section{REFERENCES}

Advokaat, E. L., van Hinsbergen, D. J. J., Maffione, M., Langereis C. G., Vissers, R. L. M., Cherchi, A., Schroeder, R., Madani, H. \& Columbu, S. (2014). Eocene rotation of Sardinia, and the paleogeography of the western Mediterranean region. Earth and Planetary Science Letters, 401, 183-195.

Almela, A. \& Ríos, J. M. (1943). Contribución al conocimiento de la zona sub-pirenaica catalana. Boletín IGME, 56, 391-451.

Andreani L., Loget, N., Rangin C. \& Le Pichon X. (2010). New structu-ral constraints on the southern Provence thrust belt (France): evidences for an Eocene shortening event linked to the Corsica-Sardinia subduction. Bulletin de la Société Géologique de France, 181, 547-563.

Bahroudi, A. \& Koyi, H. A. (2003). Tectono-sedimentary framework of the Gachsaran Formation in the Zagros foreland basin. Marine and Petroleum Geology, 21, 1295-1310.

Bello, D. A., López-Blanco, M., Muñoz, J. A., Roca, E., Casas, J. M. \& Marzo, M. (2008). Structure of the Southeastern Pyrenees frontal thrust system: stratigraphic control in both geometry and thrusting sequence. Geo-Temas, 10, 321-324.

Bestani, L., Espurt, J., Lamarche, J., Bellier, O. \& Hollender, F. (2016). Reconstruction of the Provence Chain evolution, southeastern France. Tectonics, 35, 1506-1525.

Bianca, M., Monaco, C., Tortorice, L. \& Cernobori, L. (1999). Quaternary normal faulting in southeastern Sicily (Italy): A seismic source for the 1693 large earthquake. Geophysical Journal International, 139 (2), 370-394.

Billi, A., Porreca, M., Faccenna, C. \& Mattei, M. (2006). Magnetic and structural constraints for the noncylindrical evolution of a continental forebulge (Hyblea, Italy). Tectonics, 25, TC3011.

Busquets, P. (1981). Estratigrafia i sedimentologia del Terciari prepirinenc entre els rius Llobregat i Freser - Ter. PhD Thesis. Universitat de Barcelona, Barcelona, Spain.

Calvet, F., Playà, E., Giménez-Montsant, J. \& Permanyer, A. (2007). Fifth-order cyclicity and organic matter contents relationship (Lower Eocene, Pyrenees). Geologica Acta, 5 (1), 59-75.

Carmignani, L., Funedda, A., Oggiano, G. \& Pasci, S. (2004). Tectono-sedimentary evolution of southwest Sardinia in the Paleogene: Pyrenaic or Apenninic Dynamic?. Geodinamica Acta, 17 (4), 275-287.

Carreras, J. (2001). Zooming on Northern Cap de Creus shear zones. Journal of Structural Geology, 23, 1457-1486.

Carrillo, E. (2009). Unidades evaporíticas eocenas de la Zona Surpirenaica Oriental (Área de La Garritxa). Geogaceta, 47, 73-76. 
Carrillo, E., Rosell, L. \& Ortí, F. (2014). Multiepisodic evaporitic sedimentation as indicator of palaeogeographic evolution in foreland basins (South-eastern Pyrenean basin, Early - Middle Eocene). Sedimentology, 61, 2086-2112.

Carrillo, E., Koyi, H. A., Nilfouroushan, F. (2017). Structural significance of an evaporite formation with lateral stratigraphic heterogeneities (Southeastern Pyrenean Basin, NE Spain). Marine and Petroleum Geology, 86, 1310-1326.

Casas, A., Kearey, P., Rivero, L. \& Adam, C. R. (1997). Gravity anomaly map of the Pyrenean region and a comparison of the deep geological structure of the western and eastern Pyrenees. Earth Planetary Science Letters, 150, 65-78. Calassou, S., Grimaud, F., Pauchet, H. \& Ruiz, M. (2018). The non-cylindrical crustal architecture of the Pyrenees. Scientific Reports, 8, 9591.

Christophoul, F., Soula, J. C., Brusset, S., Elibana, B., Roddaz, M., Bessiere, G. \& Deramond, J. (2003). Time, place and mode of propagation of foreland basin systems as recorded by the sedimentary fill: examples of the Late Cretaceous and Eocene retro-foreland basins of the northeastern Pyrenees. In T. McCann \& A. Saintot, Tracing Tectonic Deformation Using the Sedimentary Record (pp. 229-252). Geological Society of London, Special Publications.

Costa, J. M. (1989). Turbidites de Ripoll: Relació amb Ilurs plataformes. PhD Thesis. Universitat Autònoma de Barcelona, Cerdanyola del Vallés, Spain.

Costamagna, L. G. \& Schäfer, A. (2017). Evolution of a Pyrenean molassic basin in the Western Mediterranean area: The Eocene-Oligocene Cixerri Formation in Southern Sardinia (Italy). Geological journal, 53, 424-437.

Cotton, J. T. \& Koyi, H. A. (2000). Modelling of thrust fronts above ductile and frictional detachments: Application to structures in the Salt Range and Potwar Plateau, Pakistan. Geological Society of America Bulletin, 112, 351-363.

Cruset, D., Cantarero, I., Vergés, J., John, C. M., Muñoz-López, D. \& Travé, A. (2018). Changes in fluid regime in syn-orogenic sediments during the growth of the south Pyrenean fold and thrust belt. Global and Planetary Change, 171, 207-224. Tectonophysics, 119, 67-88.

Doglioni, C. (1995). Geological remarks on the relationships between extension and convergent Dogliont, C., Guegten, E., Harabaglia,'P. \&Mongetti, F. (1999). On the origin of west-directed subduction zones and applications to the western Mediterranean. In B. Durand, L. Jolivet, F. Horvarth \& M. Seranne, The Mediterranean Basins: Tertiary Extension within the Alpine Orogen (pp. 541-561). Geological Society of London Special Publications.

Druguet, E. (2001). Development of high thermal gradients by coeval trasnpression and magmatism during the Variscan orogeny: insights from the Cap de Creus (Eastern Pyrenees). Tectonophysics, 332, 275-293. 
Edel, J-B., Schulmann, K., Lexa, O., Diraison, M. \& Géraud, Y. (2015). Permian clockwise rotations of the Ebro and Corso-Sardinian blocks during Iberian-Armorican oroclinal bending: Preliminary paleomagnetic data from the Catalan Coastal Range (NE Spain). Tectonophysics, 657, 172-186. the crust under Corsica and Sardinia. Tectonophysics, 150, 363-389.

Estévez, A. (1970). La estructura de la Garrotxa (Gerona) en el sector comprendido entre Coma Negra y St. Joan les Fonts. Relaciones entre zócalo y cobertera. Cuadernos de Geología, Universidad de Granada, 1-2, 123-133.

Estévez, A. (1973). La vertiente meridional del Pirineo catalán al norte del curso medio del rio Fluvià. PhD Thesis. Universidad de Granada, Granada, Spain. 1:50000, 258 (Figueres). IGME, Madrid, Spain.

Gailler, A., Klingelhoefer, F., Olivet, J. L., Aslanian, D. \& Sardinia-group (2009). Crustal structure of a young margin pair: new results across the Liguro-Provencal Basin from wide-angle seismic tomography. Earth Planetary Sciences Letters, 236, 333-345.

Gich, M. (1969). Las unidades litostratigráficas del Eoceno pre-pirenaico del Ripollés oriental (prov. de Gerona y Barcelona). Acta Geológica Hispánica, 4 (1), 5-8.

873 Gimènez-Montsant, J. \& Salas, R. (1997). Subsidence analysis in thrust tectonics. Applications to 874 the southeastern Pyrenean foreland. Tectonophysics, 282, 331-352.

875 Gisbert, G., Cai, Y. \& Gimeno, D. (2019). Geodynamic history and mantle evolution recorded in 876 Cenozoic lavas of Sardinia. Journal of the Geological Society, 174, 689-703.

877 Goula, X., Olivera, C., Fleta, J., Grellet, B., Lindo, R., Rivera, L. A., Cisternas, A. \& Carbon, D. 878 (1999). Present and recent stress regime in the eastern part of the Pyrenees. Tectonophysics, $879308,487-502$.

880 Gutscher, M. A., Dominguez, S., de Lepinay, B. M., Pinheiro, L., Gallais, F., Babonneau, N., 881 Cattaneo, A., Faou, Y. L., Barreca, G., Micallef, A. \& Rovere, M. (2015). Tectonic expression of an 882 active slab tear from high-resolution seismic and bathymetric data offshore Sicily (Ionian Sea). 883 Tectonics, 35, 39-54.

884 Handy, M. R., Schmid, S. M., Bousquet, R., Kissling, E., Bernoulli, D. (2010). Reconciling plate885 tectonic reconstructions of Alpine Tethys with the geological-geophysical record of spreading 886 and subduction in the Alps. Earth-Science Reviews, 102, 121-158.

887 Horner, F. \& Lowrie, W. (1981). Paleomagnetic evidence from Mesozoic carbonate rocks for the 888 rotation of Sardinia. Journal of Geophysica, 49, 11-19.

889 Hubbard, M. S. (1999). Norumbega fault zone: part of an orogen-parallel, strike-slip sys-tem, 890 Northern Appalachians. In A. Ludman \& D. P. West Jr. (Eds.), Norumbega Fault System of the 891 Northern Appalachians (pp. 155-165). Geological Society of American.

892 Khun, D. (2002). Fold and thrust belt structures and strike-slip faulting at the SE margin of the 893 Salar de Atacama basin, Chilean Andes. Tectonics, 21, 1026.

894 Lacombe, O. \& Jolivet, L. (2005). Structural and kinematic relationships between Corsica and 895 the Pyrenees-Provence domain at the time of the Pyrenean orogeny. Tectonics, 24, TC1003. 
Le Pichon, X. \& Barbier, F. (1987). Passive margin formation by low-angle faulting within the upper crust: The Northern Bay of Biscay margin. Tectonics, 6, 133-150.

Luján, M., Storti, F., Balanyá, J.-C., Crespo-Blanc, A. \& Rossetti, F. (2003). Role of décollement material with different rheological properties in the structure of the Aljibe thrust imbricate (Flysch Trough, Gibraltar Arc): an analogue modelling approach. Journal of Structural Geology, 25, 867-881.

Macchiavelli, C., Vergés, J., Schettino, A., Fernàndez, M., Turco, E., Casciello, E., Torne, M.,

903 Pierantoni, P. P. \& Tunini, L. (2017). A New Southern North Atlantic Isochron Map: Insights Into 904 the Drift of the Iberian Plate Since the Late Cretaceous. Jo, urnal of Geophysical Research: Solid 905 Earth, 122, 9603-9626.

Malod, J. A. \& Mauffret, A. (1990). Iberian plate motion during the Mesozoic. Tectonophysics, $184,261-278$.

Malusà, M. G., Danišík, M., Kuhlemann, J. (2016). Tracking the Adriatic-slab travel beneath the Tethyan margin of Corsica-Sardinia by low-temperature thermochronometry. Gondwana

Martí, J., Mitjavila, J., Roca, E. \& Aparicio, A. (1992). Cenozoic magmatism of the Valencia trough 912 (Western Mediterranean): Relationship between structural evolution and vulcanism. Tectonophysics, 203, 145-165.

914 Martínez, A., Vergés, J. \& Muñoz, J. A. (1988). Secuencias de propagación del sistema de 915 cabalgamientos de la terminación oriental del manto del Pedraforca y relación con los conglomerados sinorogénicos. Acta Geológica Hispánica, 23 (2), 119-127.

917 Martínez, A., Vergés, J., Clavell, E. \& Kennedy, J. (1989). Stratigraphic framework of the thrust 918 geometry and structural inversion in the southeastern Pyrenees: La Garrotxa Area. Geodinamica 919 Acta, 3 (3), 185-194. Muñoz, J. A. \& Mallarach, J. M. (1994). Mapa Geológico de España 1:50000, 257 (Olot). IGME, Madrid, Spain.

Martínez, A., Rivero, L. \& Casas, A. (1997). Integrated gravity and seismic interpretation of duplex structures and imbricate thrust systems in the southeastern Pyrenees (NE Spain). Tectonophysics, 282, 303-329.

926 Martínez, A., Samsó, J. M., Zamorano, M., Picart, J., Solà, J., Montaner, J. \& Mató, E. (2000). 927 Mapa geològic de Catalunya, 1:25000, Besalú 257-2-2. Institut Cartogràfic de Catalunya, Servei 928 Geològic de Catalunya, Barcelona, Spain.

929 Martínez, A., Carrillo, E., Tallada, A. \& Copons, R. (2015). Mapa geològic de Catalunya, 1:25000, 930 Ripoll 256-1-2. Institut Cartogràfic i Geolòlogic de Catalunya, Barcelona, Spain.

931 Mató, E., Saula, E., Picart, J., Solà, J., Montaner, J., Viñals, E., Samsó, J. M., Serra-Kiel, J., Llenas, 932 M., Agustí, J. \& Mallarach, J. (1996). Mapa geològic de Catalunya, 1:25000, Banyoles 295-2-1. 933 Institut Cartogràfic i Geolòlogic de Catalunya, Barcelona, Spain.

934 McDougall, J. W. \& Khan, S. H. (1990). Strike-slip faulting in a foreland fold-thrust belt-The 935 Kalabagh Fault and western Salt Range, Pakistan. Tectonics, 9 (5), 1061-1075. 
Morley, C. K., Kongwung, B., Julapour, A. A., Abdolghafourian, M., Hajian, M., Waples, D., Warren, J., Otterdoom, H., Srisuriyon, K. \& Kazemi, H. (2009). Structural development of a major Late Cenozoic basin and transpressional belt in central Iran: The Central Basin in the Qom-Saveh area. Geosphere, 5 (4), 325-362.

Muñoz, J. A. (1992). Evolution of a continental collision belt: ECORS-Pyrenees crustal balanced section. In K. R. McClay (Ed.), Thrust Tectonics (pp. 235-246). London, Chapman and Hall.

Muñoz, J. A., Martínez, A. \& Vergés, J. (1986). Thrust sequences in the eastern Spanish Pyrenees. Journal of Structural Geology, 8, 399-405.

Muñoz, J. A., Vergés, J., Martínez, A., Fleta, J., Pujadas, J., Tosquilla, J., Samsó, J. M., Sanz, J., Saula, E., Mató, E., Barberà, M., Casas, J. M. \& Cirés, J. (1994). Mapa Geológico de España 1:50000, 256 (Ripoll). IGME, Madrid, Spain.

Muñoz, J. A., Beamud, E., Fernández, O., Arbués, P., Dinarès-Turell, J. \& Poblet, J. (2013). The Ainsa Fold and thrust oblique zone of the central Pyrenees: Kinematics of a curved contractional system from paleomagnetic and structural data. Tectonics, 32, 1142-1175.

Ortí, F., Busquets, P., Rosell, L., Taberner, C., Utrilla, R. \& Quadras, M. (1987). La fase evaporítica del Eoceno medio (Luteciense) en la Cuenca Surpirenaica Catalana. Nuevas aportaciones. Revista del Instituto de Investigaciones Geológicas, 44-45, 281-302.

Pallí, L. (1972). Estratigrafía del Paleógeno del Empordá y zonas limítrofes. PhD Thesis. Universitat Autónoma de Barcelona, Cerdanyola del Vallés, Spain.

Pallí, L., Roqué, C. \& Costa, J. M. (2011). Mapa geològic de Catalunya, 1:25000, Riudaura 2562-2. Institut Cartogràfic i Geolòlogic de Catalunya, Barcelona, Spain.

Permanyer, A., Vallés, D. \& Dorronsoro, C. (1988). Source rock potential of an Eocene carbonate slope: The Armàncies Formation of the Southern Pyrenean Basin, Northeast Spain (abstract). AAPG Mediterranean Basins Conference and Exhibition, Nice.

Peryt, T. M., Ortí, F. \& Rosell, L. (1993). Sulphate platform - basin transition of the Lower Werra Anhydrite (Zechstein, Upper Permian), Western Poland: facies and petrography. Journal of Sedimentary Petrology, 63 (4), 646-658.

Pi, E., Badia, R., Samsó, J. M., Martínez, A., Zamorano, M., Picart, J., Solà, J., Montaner, J. \& Losantos, M. (2000). Mapa geològic de Catalunya, 1:25000, Santo Llorenc de la Muga 257-2-1 (76-21). Institut Cartogràfic de Catalunya, Servei Geològic de Catalunya, Barcelona, Spain.

Prada, M., Sallares, V., Ranero, C. R., Vendrell, M. G., Grevmeyer, I., Zitellini, N. \& de Franco, R. (2013). Seismic structure of the Central Tyrrhenian basin: Geophysical constraints on the nature of the main crustal domains. Journal of Geophysical Research: Solid Earth, 119, 52-70.

Puig, C., Badia, R., Bernat, E., Díaz, E., Martínez, A., Samsó, J. M., Planagumà, LL., Mallarach, J. M., Solà, J. \& Montaner, J. (2003). Mapa geològic de Catalunya, 1:25000, Olot 257-1-2. Institut Cartogràfic de Catalunya, Servei Geològic de Catalunya, Barcelona, Spain.

Puigdefàbregas, C. \& Soler, M. (1980). Cardona Permits. The Eocene. Internal report. Unión Explosivos Rio Tinto. 
974 Puigdefàbregas, C., Muñoz, J. A. \& Marzo, M. (1986). Thrust belt development in the eastern 975 Pyrenees and related depositional sequences in the southern foreland basin. In P. A. Allen \& P. 976 Homewood (Eds.), Foreland Basins (pp. 229-246). IAS, Special Publications.

977 Puigdefàbregas, C., Muñoz, J. A. \& Vergés, J. (1992). Thrusting and foreland basin evolution in 978 the Southern Pyrenees. In K. R. McClay (Ed.), Thrust Tectonics (pp. 247-254). London, Chapman 979 and Hall.

980 Pujadas, J., Casas, J. M., Muñoz, J. A. \& Sàbat, F. (1989). Thrust tectonics and Paleogene 981 syntectonic sedimentation in the Empordà area, southeastern Pyrenees. Geodinamica Acta, 3 982 (3), 195-206.

983 Ramos, E., Busquets, P. \& Vergés, J. (2002). Interplay between longitudinal fluvial and transverse 984 alluvial fan systems and growing thrusts in a piggyback basin (SE Pyrenees). Sedimentary 985 Geology, 146, 105-131.

986 Rivero, L. (1993). Estudio gravimétrico del Pirineo Oriental. PhD Thesis. Universitat de Barcelona, 987 Barcelona, Spain.

988 Rivero, L., Vilas, M., Pinto, V. \& Casas, A. (2001). Modelización gravimétrica 2D de la fosa de 989 l’Empordà (NE de la Península Ibérica). Acta Geológica Hispánica, 36 (1-2), 97-113.

990 Rivero, L., Pinto, V. \& Casas, A. (2002). Moho depth structure of the eastern part of the

991 Pyrenean belt derived from gravity data. Journal of Geodynamics, 33, 315-332.

992 Roca, E., Sans, M., Cabrera, L. \& Marzo M. (1999). Oligocene to Middle Miocene evolution of the 993 Central Catalan margin (North-western Mediterranean). Tectonophysics, 315, 209-229.

994 Rosenbaum, G., Lister, G. S. \& Duboz, C. (2002). Relative motions of Africa, Iberia and Europe 995 during Alpine orogeny. Tectonophysics, 359, 117-129.

996 Rushlow, C. R., Barnes, J. B., Ehlers, T. A. \& Vergés, J. (2013). Exhumation of the southern 997 Pyrenean fold-thrust belt (Spain) from orogenic growth to decay. Tectonics, 32, 843-860.

998 Santisteban, C. \& Taberner, C. (1979). Facies y control tectónico de la cuenca Eocena 999 Subpirenaica Catalana. Acta Geológica Hispánica, 14, 237-241.

1000 Saula, E., Picart, J., Mató, E., Llenas, M., Losantos, M., Berástegui, X. \& Agustí, J. (1994). Evolución 1001 geodinámica de la fosa del Empordà y las Sierras Transversales. Acta Geológica Hispánica, 29 (21002 4), 55-75.

1003 Solé Sugrañes, L. (1970). Estudio geológico del Prepirineo Español entre los ríos Segre y Llobregat. 1004 PhD Thesis. Universitat de Barcelona, Barcelona, Spain.

1005 Souquet, P., Bilotte, M., Canerot, J., Debroas, E. J., Peybernes, B. \& Rey, J. (1975). Nouvelle 1006 interprétation de la structure des Pyénées. C. R. Ac. Sc. Paris, 281, 609-612.

1007 Sylvester, A. G. (1988). Strike-slip faults. Bulletin of Geological Society of America, 100 (11), 166610081703.

1009 Şengör, A. M. C. (1990). Plate tectonics and orogenic research after 25 years: Synopsis of a 1010 Tethyan perspective. Tectonophysics, 187, 315-344. 
1011 Serra-Kiel, J., Travé, A., Mató, E., Saula, E., Ferràndez-Cañadell, C., Busquets, P., Tosquella, J. \& 1012 Vergés, J. (2003). Marine and Transitional Middle/Upper Eocene Units of the Southeastern 1013 Pyrenean Foreland Basin (NE Spain). Geologica Acta, 1 (2), 177-200.

1014 Schettino, A. \& Turco, E. (2011). Tectonic history of the western Tethys since the Late Triassic. 1015 Bulletin of Geological Society of America, 123 (1-2), 89-105.

1016 Stampfli, G. M., Borel, G., Marchant, R. \& Mosar, J. (2002). Western Alps geological constraints 1017 on western Tethyan reconstructions. In Rosenbaum, G. \& Lister, G. S. (Eds.), Reconstruction of 1018 the evolution of the Alpine-Himalayan Orogen (pp. 75-104). Journal of Virtual Explorer, 8.

1019 Strohmenger, C., Voigt, E. \& Zimdars, J. (1996). Sequence stratigraphy and cyclic development 1020 of Basal Zechstein carbonate-evaporite deposits with emphasis on Zechstein 2 off-platform 1021 carbonates (Upper Permian, Northeast Germany). Sedimentary Geology, 102, 33-54.

1022 Tărăpoancă, M., Bertotti, G., Maţenco, L., Dinu, C. \& Cloetingh, S. A. P. L. (2003). Architecture of 1023 the Focs, ani Depression: A $13 \mathrm{~km}$ deep basin in theCarpathians bend zone (Romania). Tectonics, $102422(6), 1074$.

1025 Tavani, S., Vignaroli, G. \& Parente, M. (2015). Transverse versus longitudinal extensión in the 1026 foredeep-peripheral bulge system: Role of Cretaceous structural inheritances during early 1027 Miocene extensional faulting in inner central Apennines belt. Tectonics, 34, 1412-1430.

1028 Tavani, S., Bertok, C., Granado, P., Piana, F., Salas, R., Vigna, B. \& Muñoz, J. A. (2018). The Iberia1029 Eurasia plate boundary east of the Pyrenees. Earth-Science Reviews, 187, 314-337.

1030 Torelli, L., Grasso, M., Mazzoldi, G. \& Peis, D. (1998). Plio-Quaternary tectonic evolution and 1031 structure of the Catania foredeep, the northern Hyblean Plateau and the Ionian shelf (SE Sicily). 1032 Tectonophysics, 298, 209-221.

1033 Tosquella, J. \& Samsó, J. (1998). Bioestratigrafía y litoestratigrafía del Paleoceno Superior1034 Eoceno Inferior del sector oriental de la Cuenca Surpirenaica. Acta Geológica Hispánica, 31, (11035 3), 3-21.

1036 Turco, E., Macchiavelli, C., Mazzoli, S., Schettino, A. \& Pierantoni, P. P. (2012). Kinematic 1037 evolution of Alpine Corsica in the framework of Mediterranean mountain belts. Tectonophysics, 1038 579, 193-206.

1039 Turner, S. A., Cosgrove, J. W. \& Liu, J. G. (2010). Controls on lateral structural variability along 1040 the Keping Shan Thrust Belt, SW Tien Shan Foreland, China. Geological Society of London, Special 1041 Publications, 348, 71-85.

1042 Vacherat, A., Mouthereau, F., Pik, R., Huyghe, D., Paquette, J.-L. \& Christophoul, F. (2017). Rift1043 to-collision sediment routing in the Pyrenees: A synthesis from sedimentological, 1044 geochronological and kinematic constraints. Earth-Science Reviews, 172, 43-74.

1045

1046

1047 van Hinsbergen, D. J. J., Vissers, R. L. M. \& Spakman, W. (2014). Origin and consequence of western Mediterranean subduction, rollback, and slab segmentation. Tectonics, 33, 393-419.

Vegas, R. \& Banda, E. (1982). Tectonic framework and Alpine evolution of the Iberian Peninsula. Earth Evolution Sciences, 4, 320-343.

Vergés, J. (1993). Estudi geológic del vessant sud del Pirineu oriental i central. Evolució cinemàtica en 3D. PhD Thesis. Universitat de Barcelona, Barcelona, Spain. 
1051 Vergés, J. \& Burbank, D. W. (1996). Eocene-Oligocene thrusting and basin configuration in the 1052 eastern and central Pyrenees (Spain). In P. F. Friend \& C. J. Dabrio (Eds.), Tertiary Basins of Spain 1053 (pp. 120-133). Cambridge University Press.

1054 Vergés, J. \& Martínez, A. (1988). Corte compensado del Pirineo oriental: geometría de las 1055 cuencas de antepaís y edades de emplazamiento de los mantos de corrimiento. Acta Geológica 1056 Hispánica, 23 (2), 95-106.

1057 Vergés, J. \& Sàbat, F. (1999). Constraints on the Neogene Mediterranean kinematic evolution 1058 along a $1000 \mathrm{~km}$ transect from Iberia to Africa. Geological Society of London, Special 1059 Publications, 156, 63-80.

1060 Vergés, J., Martínez, A., Domingo, F., Muñoz, J. A., Losantos, M., Fleta, J. \& Gisbert, J. (1994). 1061 Mapa Geológico de España 1:50000, 255 (La Pobla de Lillet). IGME, Madrid, Spain.

1062 Vergés, J., Marzo, M., Santaeularia, T., Serra-Kiel, J., Burbank, D. W., Muñoz, J. A. \& Gimènez1063 Montsant, J. (1998). Quantified vertical motions and tectonic evolution of the SE Pyrenean 1064 foreland basin. In A. Mascle, C. Puigdefàbregas, H. P. Luterbacher \& M. Fernández (Eds.), 1065 Cenozoic Foreland Basins of Western Europe (pp. 107-134). Geological Society of London, Special 1066 Publications.

1067 Vidal-Pardal, M. (1954). La alimentación subterránea del lago de Bañolas. Revista de Obras 1068 Publicas, 2869, 223-227.

1069 Vidal-Royo, O., Koyi, H. A. \& Muñoz, J. A. (2009). Formation of orogen-perpendicular thrusts 1070 due to mechanical contrasts in the basal décollement in the Central External Sierras (Southern 1071 Pyrenees, Spain). Journal of Structural Geology, 31, 523-539.

1072 Zhao, M. \& Jacobi, R. D. (1997). Formation of regional cross-fold joints in the northern 1073 Appalachian Plateau. Journal of Structural Geology, 19, 817-834.

1074

1075

1076

1077

1078

1079

1080

1081

1082

1083

1084

1085

1086 
Table 1. Main lithologies, interval velocities and densities of the lithostratigraphic units.

\begin{tabular}{|c|l|c|c|}
\hline Stratigraphy & \multicolumn{1}{|c|}{ Lithology } & Velocity $\mathbf{( m / s )}$ & Density $\left(\mathbf{g} / \mathbf{c m}^{\mathbf{3}}\right)^{*}$ \\
\hline \multirow{3}{*}{ Bellmunt sequence } & $\begin{array}{l}\text { Conglomerates, } \\
\text { sandstones and } \\
\text { marls }\end{array}$ & $3000-4900$ & $2.45-2.60$ \\
\hline \multirow{5}{*}{ Serrat Evaporites } & $\begin{array}{l}\text { Siltstone, sandstone, } \\
\text { limestone, dolostone } \\
\text { and anhydrite }\end{array}$ & $4700-4900$ & 2.72 \\
& $\begin{array}{l}\text { Anhydrite, } \\
\text { dolostone, limestone } \\
\text { and marl }\end{array}$ & $5300-5700$ & 2.83 \\
\cline { 2 - 4 } & Anhydrite & $6000-6100$ & 2.90 \\
\cline { 2 - 4 } & Shale and anhydrite & 4600 & 2.70 \\
\cline { 2 - 4 } & Salt & 4300 & 2.10 \\
\hline \multirow{3}{*}{ Presalt group } & $\begin{array}{l}\text { Limestone and } \\
\text { dolostone }\end{array}$ & $5100-5600$ & 2.67 \\
\cline { 2 - 4 } & $\begin{array}{l}\text { Shale, marl and } \\
\text { limestone }\end{array}$ & 4900 & 2.63 \\
\hline \multirow{2}{*}{ Basement } & Granite & 5500 & 2.64 \\
\cline { 2 - 4 } & $\begin{array}{l}\text { Schist, sandstone } \\
\text { and limestone }\end{array}$ & 5500 & 2.72 \\
\hline
\end{tabular}

* Extracted from previous works (Martínez et al., 1997; Rivero et al., 2001; Carrillo et al., 2014).

1090

Figure 1. Regional setting. (A) Overview of the Western Mediterranean Region at present-day showing the location of the Southeastern Pyrenees (rectangle, Fig. 2A), the main geographic features, structures (yellow lines) and basins (annotated Google Earth image). Structures are based on Vergés (1993) and Doglioni et al. (1999). (CCR) Catalan Coastal Range. (NBFZ) Northern Balearic Fracture Zone. (B) Paleogeographic map (after Lacombe and Jolivet, 2005; Advokaat et al., 2014; Vacherat et al., 2017) showing the interactions between Iberia, Eurasia, Adria, Africa, Sardinia and Corsica during the Early Eocene. Paleogeographic information is based on Martínez et al. (1994), Christophoul et al. (2003), Carmignani et al. (2004), Andreani et al. (2010) and Costamagna and Schäfer (2017). Plate motions are extracted from Malusà et al. (2016) and Macchiavelli et al. (2017).

Figure 2. The Southeastern Pyrenees. (A) Geological map of the Southeastern Pyrenees (modified from Carrillo et al., 2014) displaying thrust sheets (TS) and other structural features. Rectangle indicates the study area and strike line location of a cross-section. (B) Structural crosssection (see A for location, based on Carrillo et al., 2017) where the main structural features are presented. Structural features: (CTF) Central Transverse Fault; (ETF) Eastern Transverse Fault; (RS) Ripoll syncline; (WTF) Western Transverse Fault; and (VT) Vallfogona thrust.

Figure 3. Chart showing age and stratigraphic, seismic and structural features of the sedimentary record in the Ebro (A) and Empordà (B) basins (based on Almela and Ríos, 1943; Gich, 1969; Solé Sugrañes, 1970; Pallí, 1972; Estévez, 1973; Puigdefàbregas and Soler, 1980; Busquets, 1981; Ortí 
et al., 1987; Permanyer et al., 1988; Martínez et al., 2000; Pi et al., 2000; Carrillo et al., 2014, 2017). Age abbreviations: (PZ) Paleozoic; (K) Cretaceous; and (P) Paleocene. Stratigraphic abbreviations: (B) Basement; (LP) Lower Presalt; (UP) Upper Presalt; (SE) Serrat Evaporites; (S) Suprasalt; and (BS) Bellmunt Sequence. TVT represents true vertical thickness and TWT twoway-time.

Figure 4. Study area (see Fig. 2A for location). (A) Database map showing seismic lines, exploration wells and gravity measurements. (B) Geological map where the lithostratigraphic units, the main structures, exploration wells and stratigraphic and key sections are displayed (modify from Muñoz et al., 1994; Martínez et al., 2000; Pi et al., 2000; Carrillo et al., 2017). Exploration wells: (A2) Ampurdan-2; (B1) Bestrecà-1; (B2) Banyoles-2; (B4) Besalú-4; (R1) Riudaura-1; (R2) Riudaura-2; (S1) Serrat-1; and (V1) Vallfogona-1. Structures: (CTF) Central Transverse Fault; (ETF) Eastern Transverse Fault; (RS) Ripoll syncline; (WTF) Western Transverse Fault; and (VT) Vallfogona thrust.

Figure 5. Key sections (see Fig. 4B for locations) illustrating seismic lines (above) and geoseismic sections (below). Triangles, situated on the tops, indicate intersections with other lines and sections. In the seismic lines, lithostratigraphic markers from exploration wells and the location of detailed lines and sections (rectangles in c and d) are displayed. In the geoseismic sections, the main structures and their relation with the lithostratigraphic units at the present day are shown on the basis of the lithostratigraphic markers, seismic lines and surface information. (CTF) Central Transverse Fault; (WTF) Western Transverse Fault.

Figure 5. Continued.

Figure 6. Structural maps in the autochthonous zone for the top Basement $(A)$, in depth-time referred to a seismic datum, and the autochthonous and allochthonous zones for the top Serrat Evaporites (B), in height referred to the present day sea level, where the main faults and folds (black and dashed white lines), the present day location of the Vallfogona thrust (red lines) and exploration wells (circles) are displayed. Exploration wells: (A2) Ampurdan-2; (B1) Bestrecà-1; (B4) Besalú-4; (R1) Riudaura-1; (R2) Riudaura-2; (S1) Serrat-1; and (V1) Vallfogona-1.

Figure 7. Isopach maps in the autochthonous zone for the Presalt group and the Serrat Evaporites (A and B), in time (0.05 s TWT counter interval), and the autochthonous and allochthonous zones for the Suprasalt group (C), in thickness (100 m counter interval), illustrating the main faults (black and dotted white lines), the present day location of the Vallfogona thrust (red lines) and exploration wells (labelled circles). Exploration wells: (A2) Ampurdan-2; (B1) Bestrecà-1; (B4) Besalú-4; (R1) Riudaura-1; (R2) Riudaura-2; (S1) Serrat-1; and (V1) Vallfogona-1. 
Figure 8. Stratigraphic correlations in the autochthonous zone (A) and the allochthonous zone (B) on the basis of exploration wells and stratigraphic sections (see Fig. 4B for locations), where the lithostratigraphic units and the main structural features are shown. In the autochthonous and allochthonous zones the datum are the tops of the Beuda Formation and a gypsum interval within the Bellmunt sequence, respectively.

Figure 9. Detailed seismic lines (above) and geoseismic sections (below) in the Empordà Basin (A, see Fig. 5C for location) and the Cadí thrust sheet (B, see Fig. 5D for location). The geoseismic sections show the lithostratigraphic units and the main structural and stratigraphic features. Lithostratigraphic units: (B) Basement; (PS) Presalt group; (SE) Serrat Evaporites; (S) Suprasalt; and (BS) Bellmunt sequence. (VT) Vallfogona thrust.

Figure 10. Two-dimensional inversion gravity models (calculated) versus the measured residual gravity (above) in three key sections (below). Triangles, situated on the tops, indicate intersections with other models. In the key sections, the main structures and their relation with lithologies at the present day are shown. Location of the Central model (A), Eastern model (B) and Northern model (C) correspond to the position of figures $5 B, C$ and $D$ (see Fig. 3B), respectively. (CTF) Central Transverse Fault; (ETF) Eastern Transverse Fault; (WTF) Western Transverse Fault.

Figure 11. Paleogeographic maps of the restored study area for the tectono-sedimentary evolution stages, illustrating the sedimentary environments, structural features, paleodrainages and the present day location of the exploration wells (circles): (A) Stage 1, the Presalt group, Late Paleocene to Early Eocene (57 to $51 \mathrm{Ma}$ ); (B) Stage 2, the Serrat Evaporites, Early to Middle Eocene (51 to $49 \mathrm{Ma}$ ); and (C) Stage 3, the Suprasalt group, Middle Eocene (49 to $44 \mathrm{Ma}$ ). Structures: (CTF) Central Transverse Fault; (ETF) Eastern Transverse Fault; (WTF) Western Transverse Fault. Exploration wells: (A2) Ampurdan-2; (B1) Bestrecà-1; (B4) Besalú-4; (R1) Riudaura-1; (R2) Riudaura-2; (S1) Serrat-1; and (V1) Vallfogona-1.

Figure 12. Crustal-scale cross-sections across the Southeastern Pyrenees from the low-relief thrust system, in Iberia, to the basement high, in Sardinia, during the first (A) and second tectonic phases (B) showing the interactions between Iberia and Sardinia from Late Paleocene to Middle Eocene. The sections illustrate the study area's lithological, paleogeographical and paleoenviromental context as well as main structures. Apatite U-Th/He (AHe) and apatite fission track (AFT) ages are also show (from Rushlow et al., 2013 and Malusà et al., 2016). In the Sardinian domain, the geological information is extracted from Carmignani et al. (2004) and Costamagna and Schäfer (2017). 



Figure 1: Regional setting 

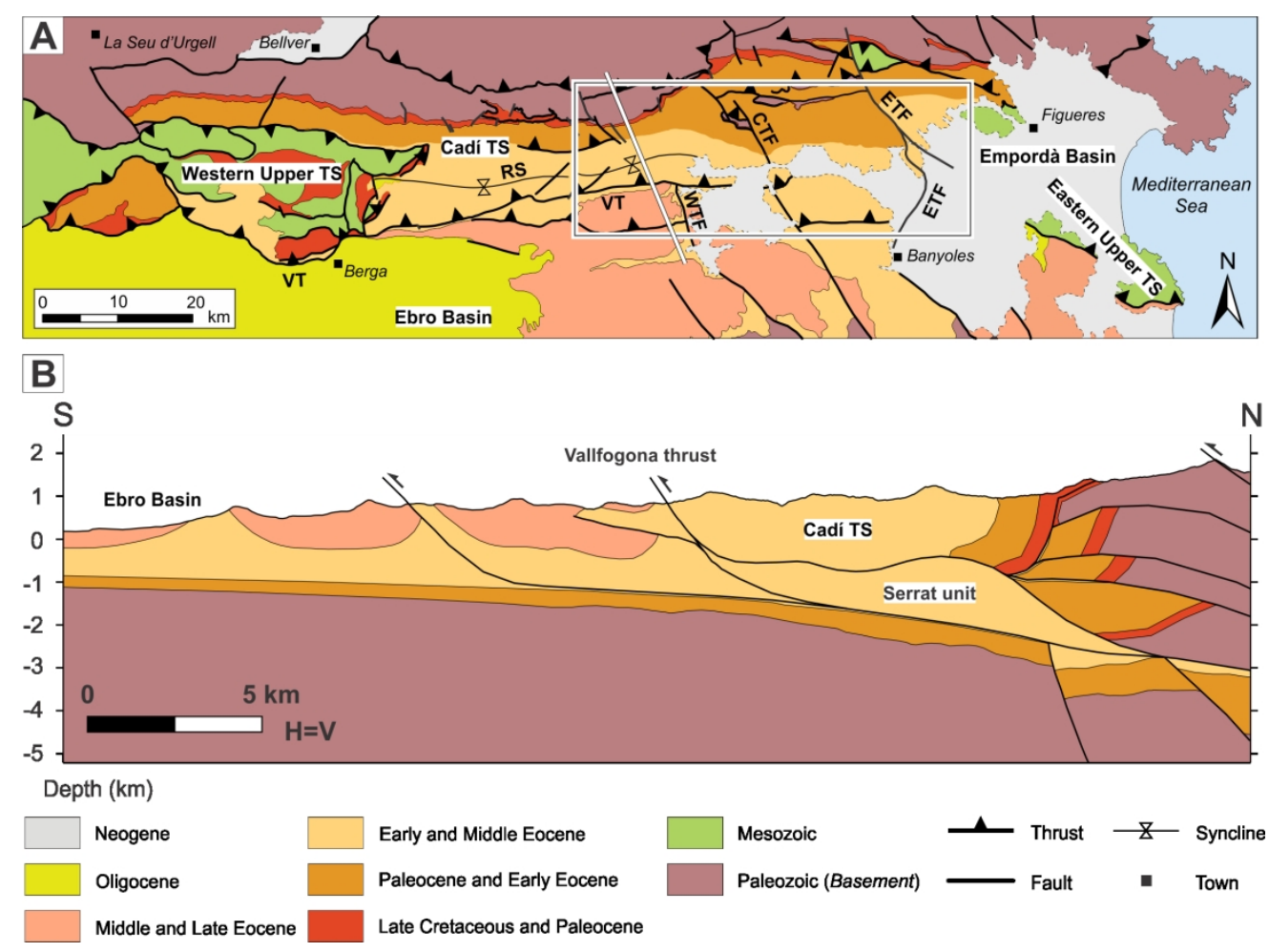

Figure 2: Southeastern Pyrenees 

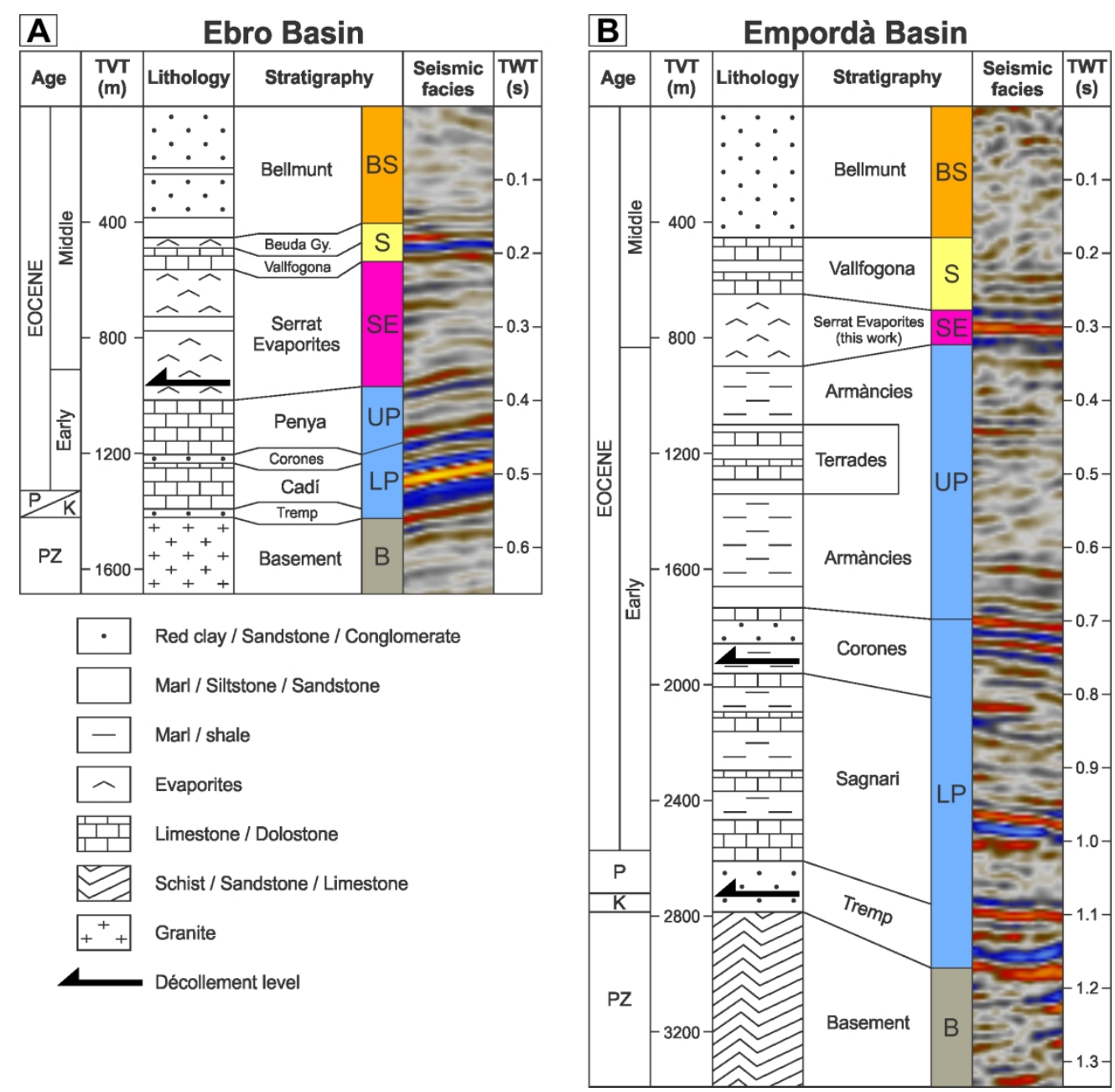

Figure 3: Stratigraphic framework 


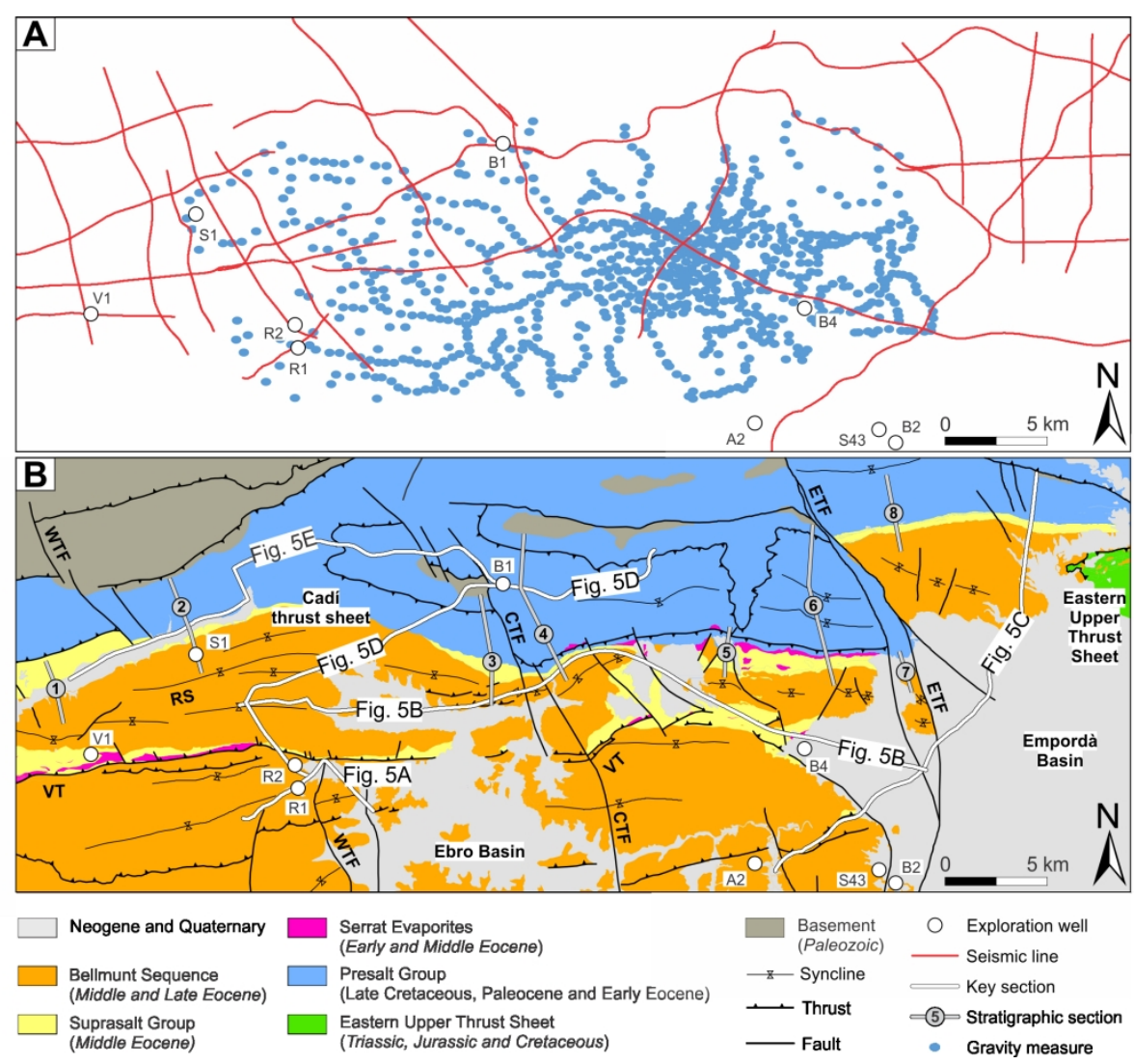

Figure 4: Study area 


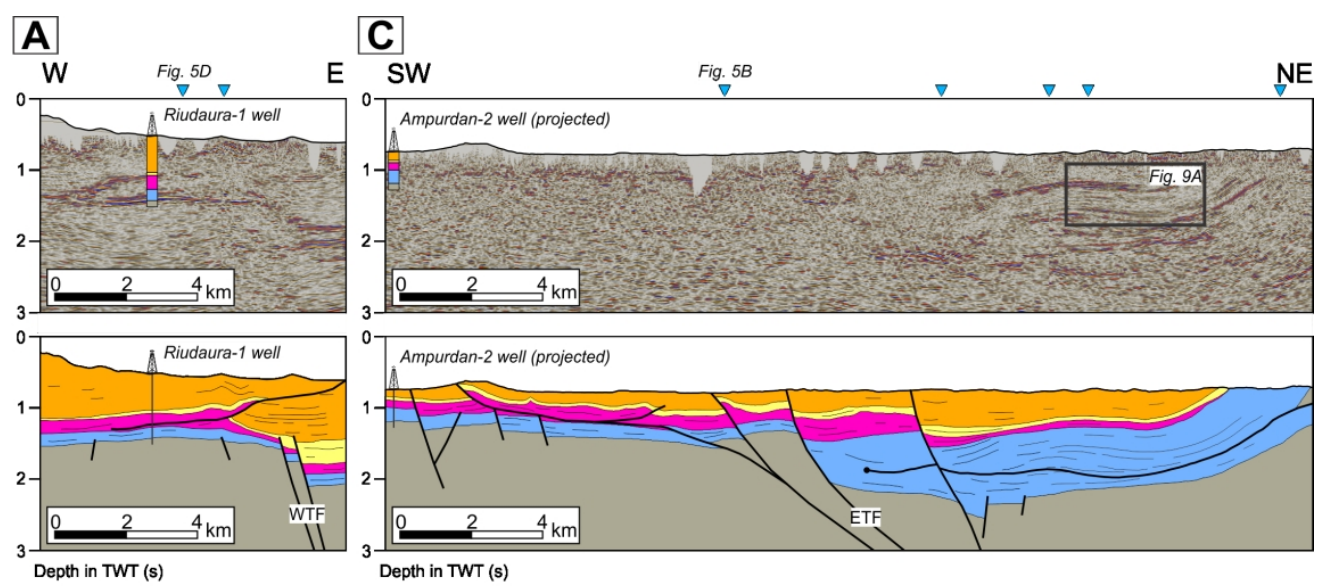

\section{B}


Figure 5: Seismic interpretation 


\section{D}
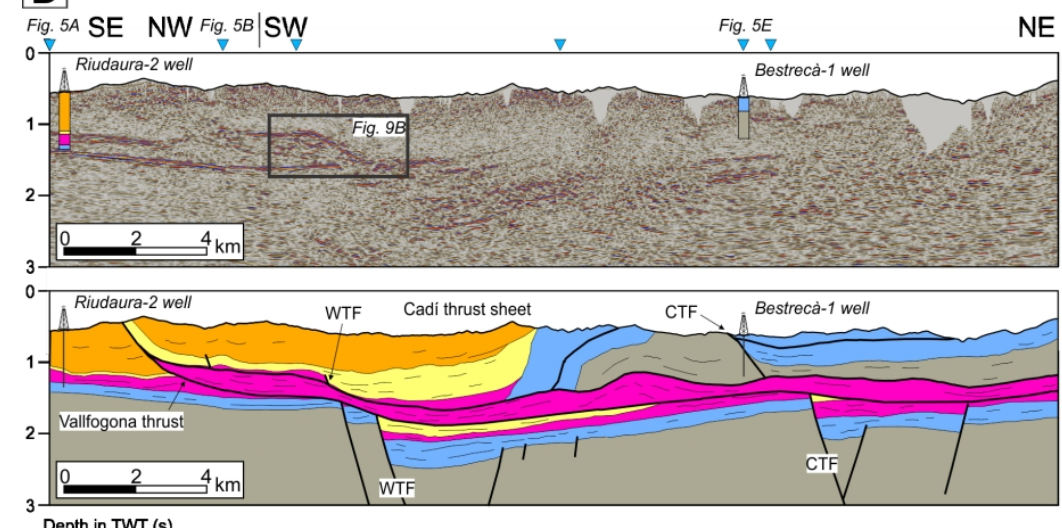

E



Figure 5: Continued 



Figure 6: Structural maps 

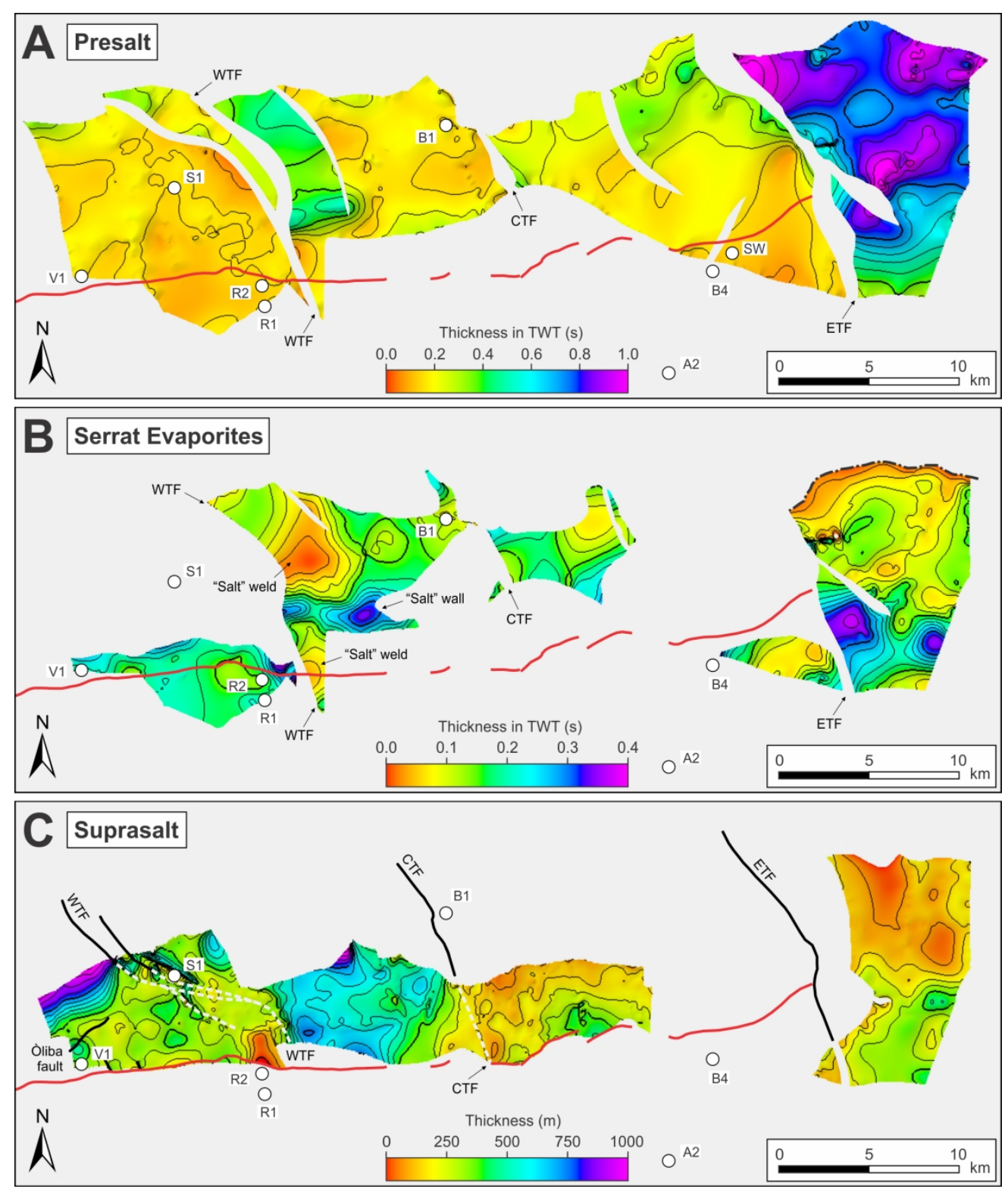

Figure 7: Isopach maps 

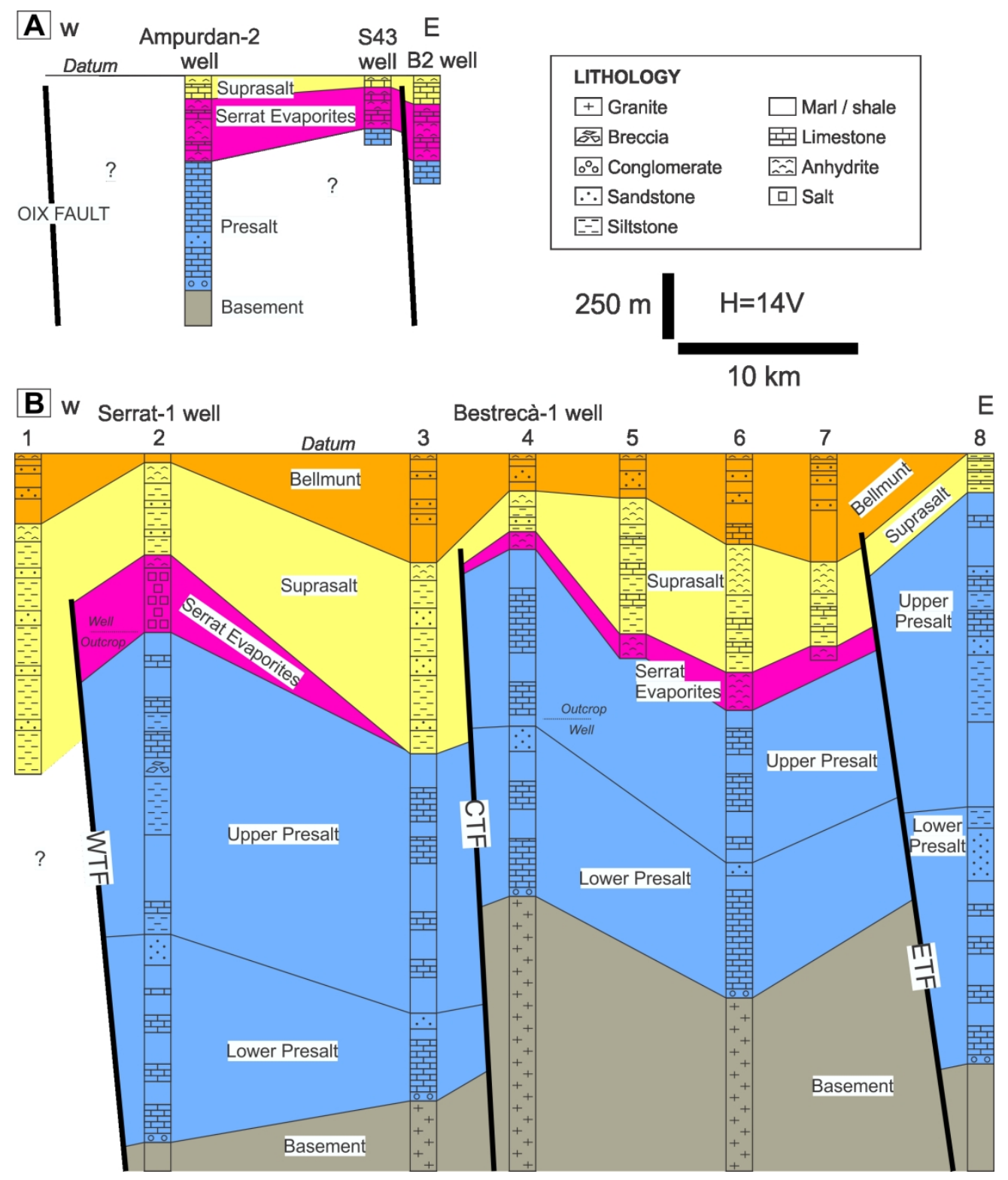

Figure 8: Stratigraphic correlation 


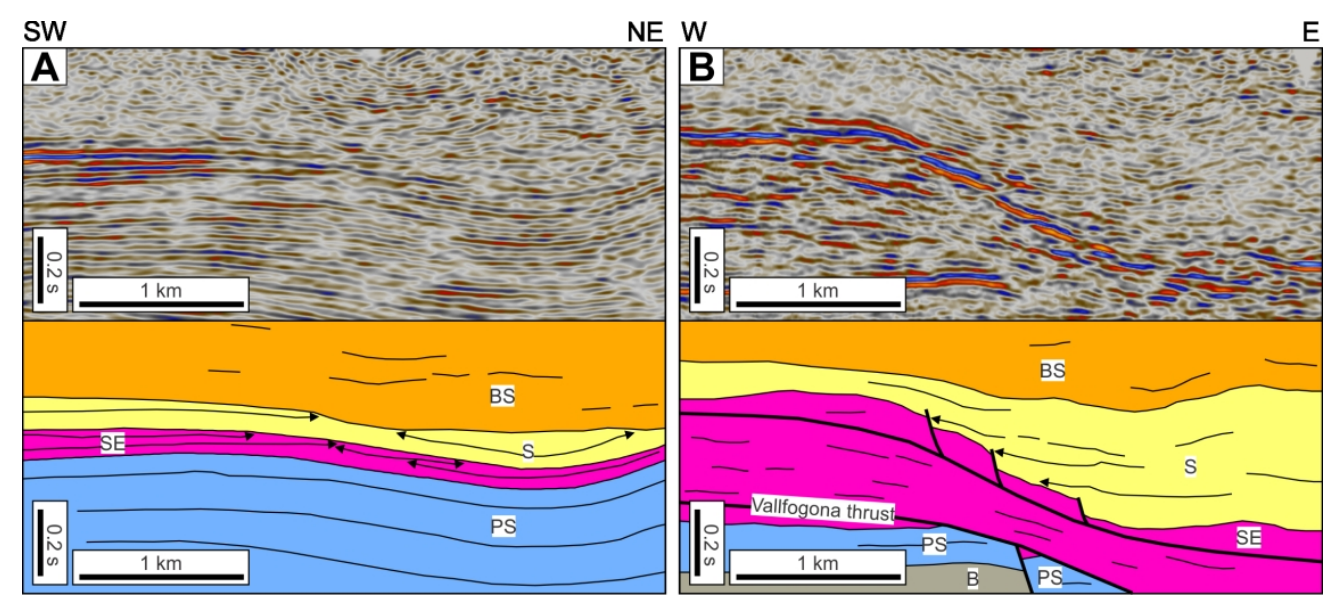

Figure 9: Sismo-stratigraphic relationships 

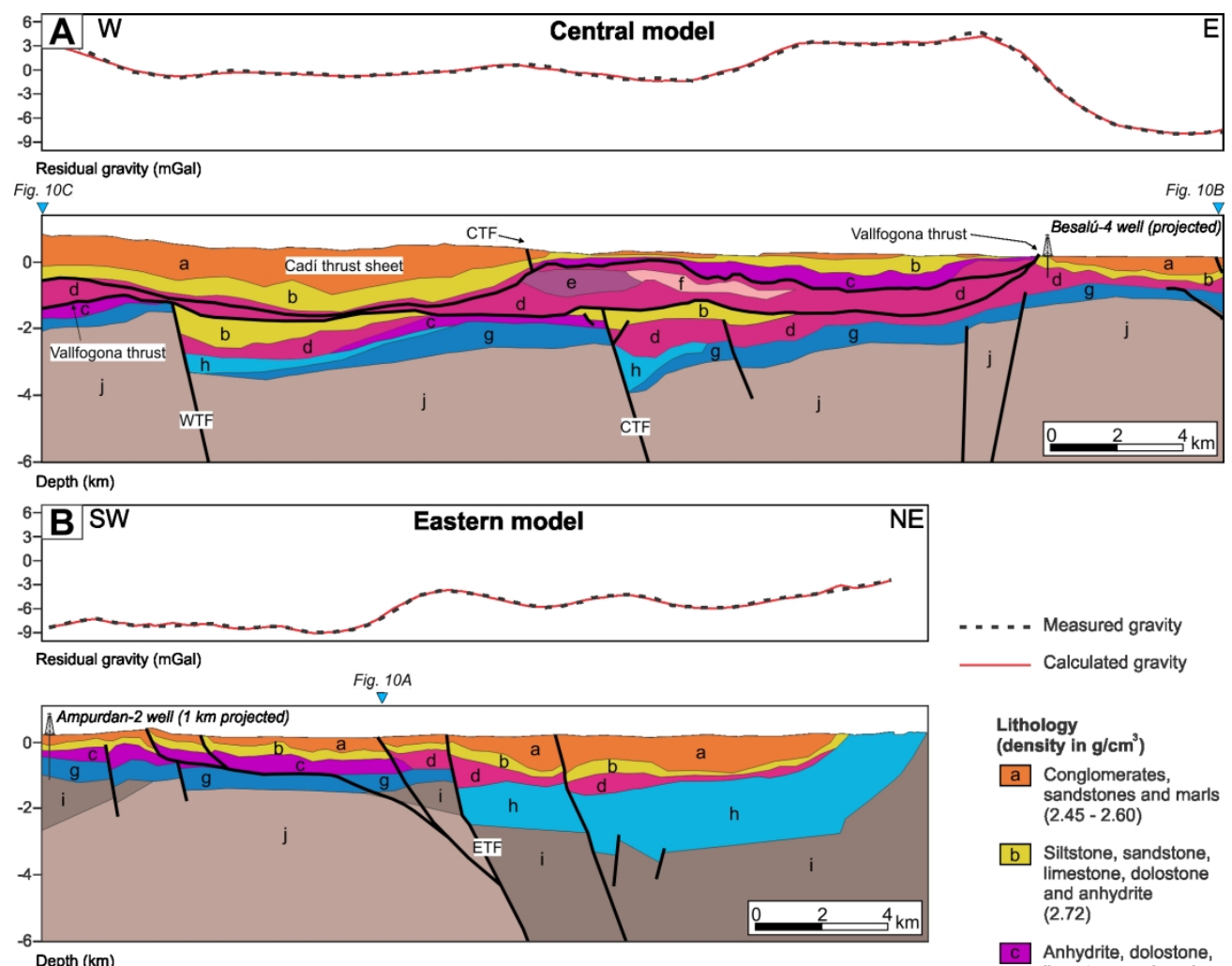

Lithology

(density in $\mathrm{g} / \mathrm{cm}^{3}$ )

a Conglomerates, sandstones and marls $(2.45-2.60)$

b Siltstone, sandstone limestone, dolostone and anhydrite (2.72)

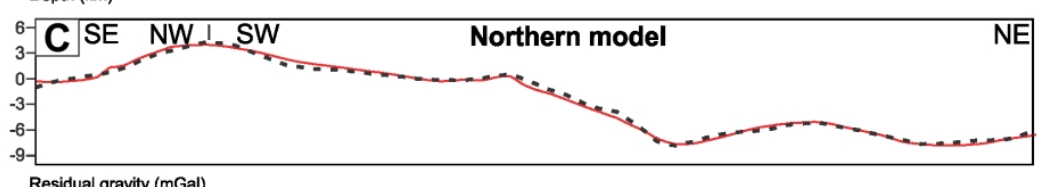

Anhydrite, dolostone limestone and marl (2.83)

d Anhydrite (2.90)

e Shale and anhydrite (2.70) Residual gravity (mGal)
Fig. $10 \mathrm{~A}$

$f$ Salt

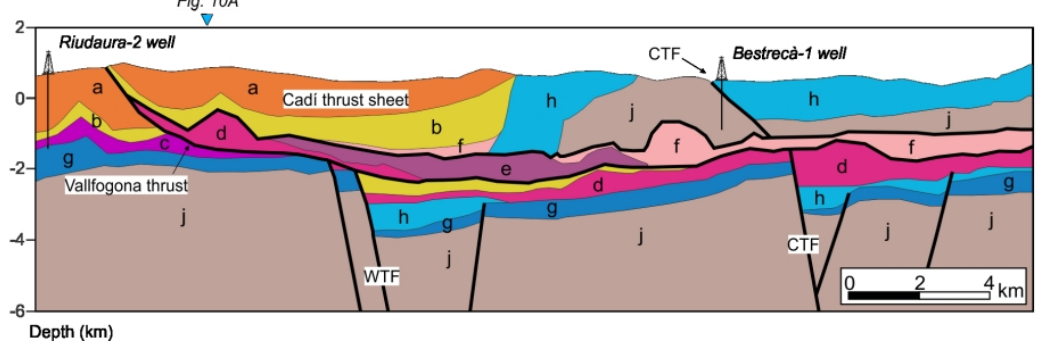

(2.10)

g Limestone and dolostone (2.67)

h Shale, marl and limestone (2.63)

i Schist, sandstone and limestone (2.72)

Granite
$(2.64)$

Figure 10: Gravity modelling 

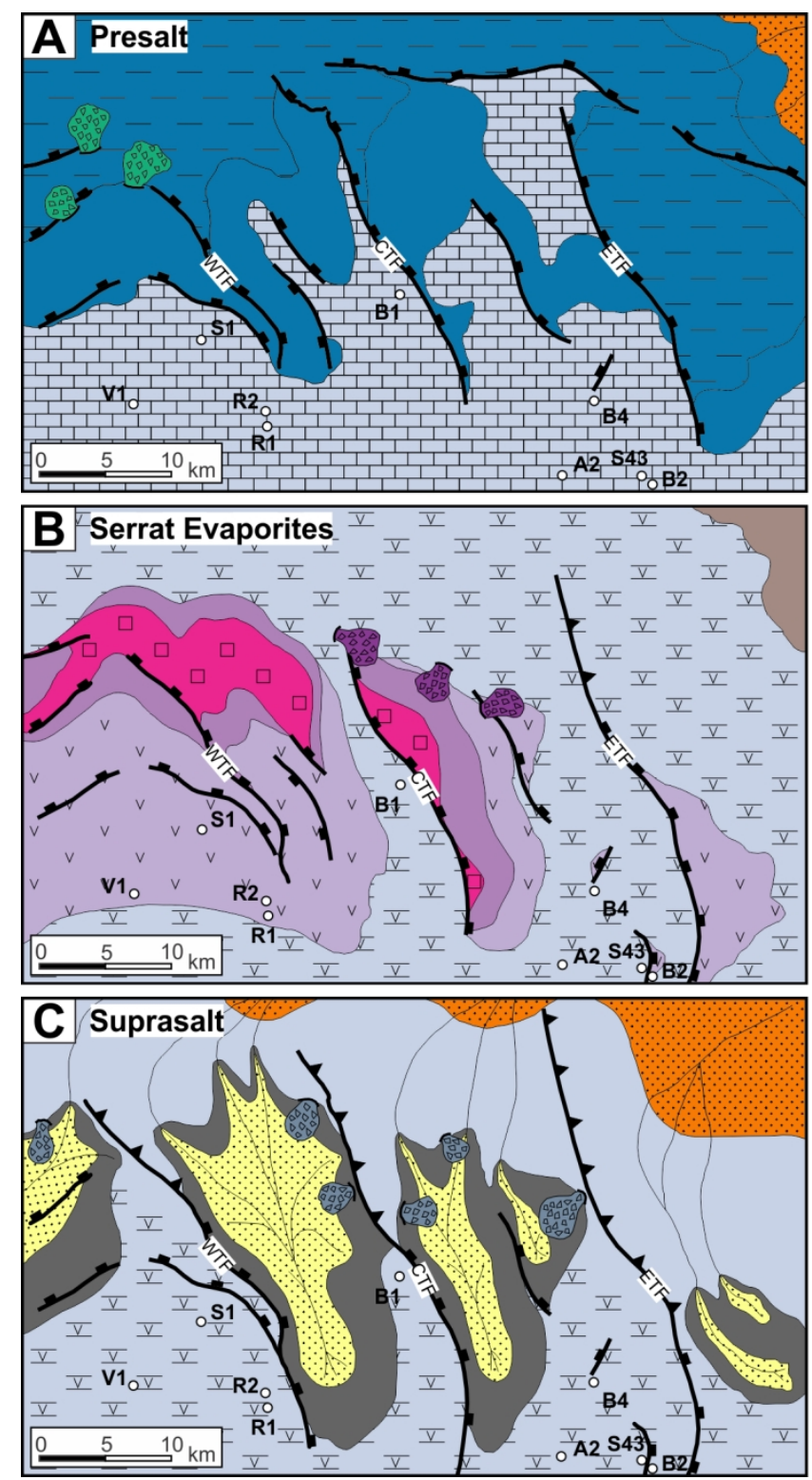

\section{Carbonate}

Shallow platform

Transition

Deep platform

Carbonate breccia

\section{Evaporite}

$\checkmark$ Selenitic wedge or basin

Sulphate and shale transition

Salt deep basin

Sulphate breccia

\section{Siliciclastic}

$\because$ Fluvial and delta plain

Slope

Submarine fan

\section{Mixed}

$\square$ Siliciclastic/Carbonate shelf Carbonate / Sulphate shelf

Siliciclastic / Sulphate breccia

Subaerial land

\section{Faulting}

Stretching

Contractional

Tectono-sedimentary evolution 


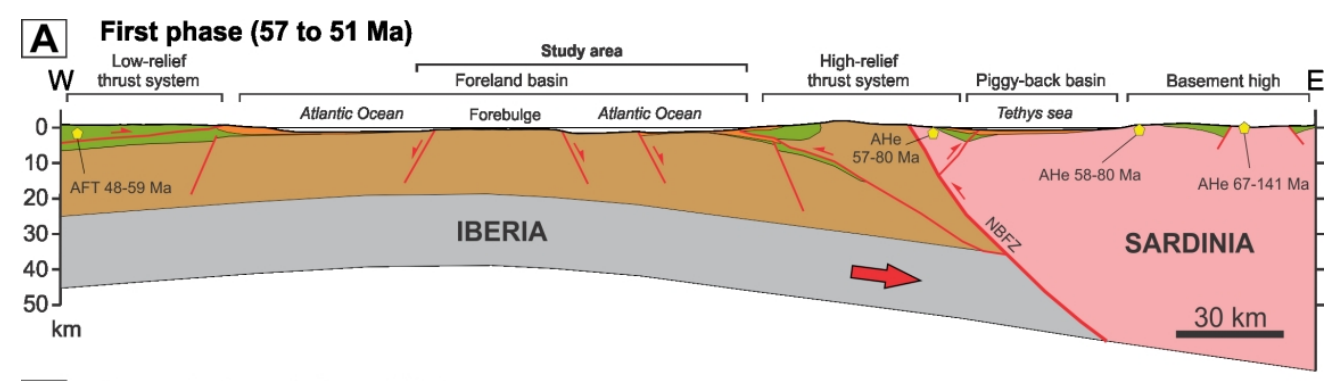

\section{B Second phase (51 to $44 \mathrm{Ma}$ )}

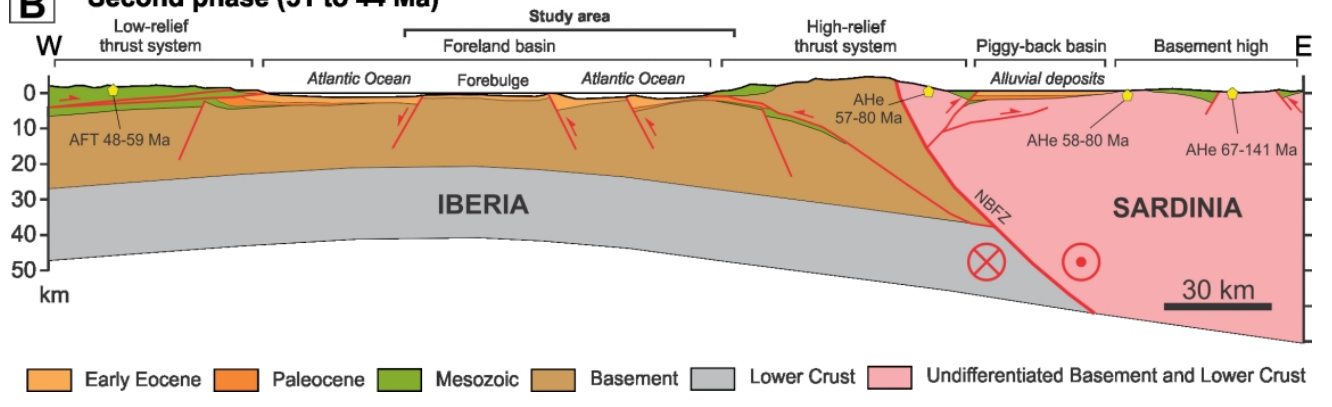

Figure 12: Tectonic response 